Rhode Island College

Digital Commons @ RIC

$12-1-2019$

\title{
A Systematic Review Comparing Neostigmine Versus Sugammadex
}

Brittany Williams

Follow this and additional works at: https://digitalcommons.ric.edu/etd

Part of the Nursing Commons

\section{Recommended Citation}

Williams, Brittany, "A Systematic Review Comparing Neostigmine Versus Sugammadex" (2019). Master's Theses, Dissertations, Graduate Research and Major Papers Overview. 321.

https://digitalcommons.ric.edu/etd/321

This Major Paper is brought to you for free and open access by the Master's Theses, Dissertations, Graduate Research and Major Papers at Digital Commons @ RIC. It has been accepted for inclusion in Master's Theses, Dissertations, Graduate Research and Major Papers Overview by an authorized administrator of Digital Commons @ RIC. For more information, please contact digitalcommons@ric.edu. 



\section{A SYSTEMATIC REVIEW COMPARING NEOSTIGMINE VERSUS \\ SUGAMMADEX \\ FOR REVERSAL OF ROCURONIUM-INDUCED \\ NEUROMUSCULAR BLOCKADE}

A Major Paper Presented

by

Brittany Williams

Approved:

Committee Chairperson

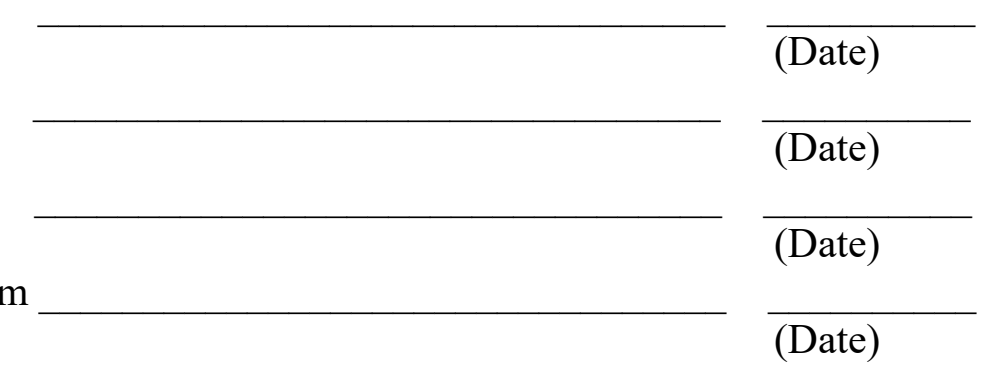

Dean, School of Nursing 


\title{
A SYSTEMATIC REVIEW COMPARING NEOSTIGMINE VERSUS SUGAMMADEX \\ FOR REVERSAL OF ROCURONIUM-INDUCED NEUROMUSCULAR BLOCKADE
}

\section{Brittany Williams}

\author{
A Major Paper Submitted in Partial Fulfillment \\ of the Requirements for the Degree of \\ Master of Science in Nursing \\ in
}

The School of Nursing

Rhode Island College

2019 


\begin{abstract}
Postoperative residual muscle paralysis can lead to very serious complications, such as hypoxia, airway obstruction, and generalized muscle weakness after surgical procedures. Traditional anesthesia practice has utilized a class of medications called cholinesterase inhibitors to mitigate these complications. Cholinesterase inhibiting agents have the potential to create adverse effects of their own, such as bradycardia, due to the drug class's indirect mechanism of action. An ideal reversal agent would reverse quickly, and reliably, with minimal adverse effects. Recently, sugammadex, a selective relaxantbinding agent, has been introduced as an alternative reversal agent. The purpose of this systemic review was to compare the administration of sugammadex versus neostigmine and time to re-establish normal muscular function, as evidenced by a train-of-four (TOF) ratio of 0.9. Databases were searched for pertinent randomized control trials and literature regarding the topic of this review. Inclusion and exclusion criteria were utilized to finalize the five studies that were included in this systematic review. The PRISMA checklist and CASP tool was utilized to extract and critically appraise each study. Additionally, a cross study analysis was performed. Overall, sugammadex was found to be a faster and more reliable reversal agent, with mild-to-moderate adverse effects reported, when compared to the anticholinesterase, neostigmine. Consistently and reliably reversing neuromuscular blocking agents and educating other health care professionals about the negative consequences of postoperative residual muscle paralysis, are initiatives that the advance practice nurse, particularly the CRNA, can lead.
\end{abstract}




\section{Table of Contents}

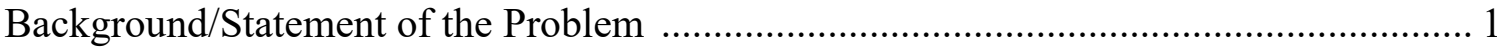

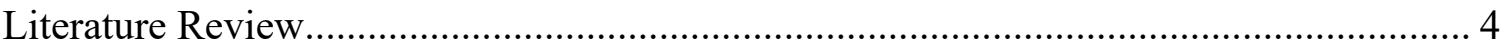

Theoretical Framework.............................................................

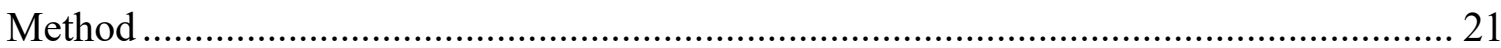

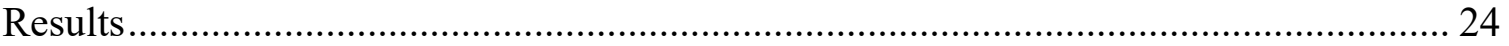

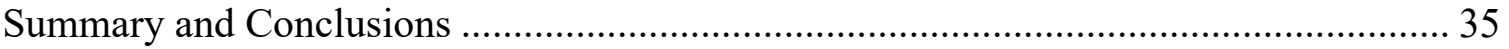

Recommendations and Implications for Advanced Nursing Practice ........................... 38

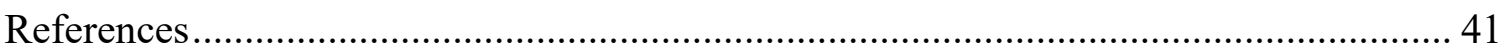

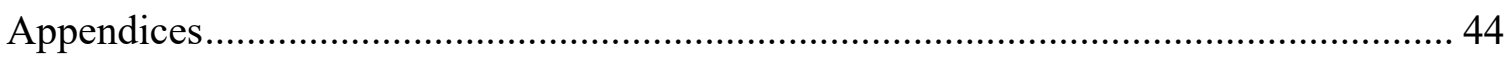


A Systematic Review Comparing Neostigmine Versus Sugammadex For Reversal of Rocuronium-Induced Neuromuscular Blockade

\section{Background/Statement of the Problem}

Muscle relaxation induced by neuromuscular blocking agents (NMBAs) has been commonly used in anesthesia practice to enable paralysis. NMBAs facilitate tracheal intubation by paralyzing the vocal cords, allowing an endotracheal tube to pass without causing laryngeal trauma. Additionally, the paralysis induced by NMBAs during surgery assists to optimize surgical conditions by relaxing the skeletal musculature, inhibiting reflexive movement to noxious surgical stimuli, and inhibiting spontaneous ventilation (Kirkland, 2013).

In the United States, routine practice of reversing non-depolarizing NMBAs varies amongst anesthesia providers. The potential for residual paralysis caused by an incomplete non-depolarizing NMBA reversal could negatively impact patients in the post-operative period. Post-operative residual paralysis (PORP), defined as muscle weakness due to incomplete or absent antagonism of non-depolarizing neuromuscular blockers, has been shown to increase morbidity and mortality (Mathias \& Bernardis, 2012). Mathias and Bernardis (2012) identified complications of residual paralysis to include: increased risk of regurgitation due to weakness in the hypoglossal and esophageal sphincter muscles, hypoxia, airway obstruction, generalized muscle weakness, and difficulty speaking or drinking. The primary prevention strategy for PORP and subsequent complications has been pharmacologic reversal, which ensures safety and termination of the NMBA effect (Kirkland, 2013).

Anesthesia practice has traditionally reversed neuromuscular blockade with a cholinesterase inhibitor, neostigmine, administered concurrently with an anticholinergic 
agent, such as atropine or glycopyrrolate. Cholinesterase inhibitors work indirectly, increasing the amount of acetylcholine available within the neuromuscular junction (NMJ), to compete for binding sites on the muscle's nicotinic acetylcholine receptor (Welliver, 2013). Limitations and adverse effects exist with the use of cholinesterase inhibitors due to the drug's indirect mechanism of action. Adverse effects of cholinesterase inhibitors result from excess acetylcholine and include: bradycardia, increased gastric motility, airway secretions, bronchoconstriction, and arrhythmias (Nagelhout, 2013). An anticholinergic agent administered concurrently with cholinesterase inhibitors has traditionally been used to blunt the degree of adverse effects. One of the main limitations of using cholinesterase inhibitors has been the inability to produce a consistent and reliable train-of-four (TOF) ratio of 0.9 within 30 minutes (Nagelhout, 2013). TOF, a method of nerve stimulation, utilizes a peripheral nerve stimulator (PNS) to deliver four electrical impulses every 0.5 seconds at a frequency of two hertz for a total of two seconds, to determine depth of neuromuscular blockade (Nagelhout \& Plaus, 2014). Each of the four impulses causes a muscle twitch, referred to as $T_{1}$ through $T_{4}$. The TOF ratio uses an accelerometer to quantitatively compare the last twitch, $\mathrm{T}_{4}$, to the first twitch, $\mathrm{T}_{1}$, to yield a numeric ratio.

The varying degree of effectiveness and unpleasant side effects of cholinesterase inhibitors led to the investigation of alternative reversal agents. Ideally, a reversal agent would provide a rapid onset, produce minimal adverse effects, and re-establish muscle function reliably and consistently, regardless of neuromuscular blockade depth (Nagelhout, 2013). 
Sugammadex, a reversal agent specific for the aminosteroid class of nondepolarizing NMBAs, was initially studied with the intent that the compound would increase the solubility of the NMBA, rocuronium, in specific media. However, while under investigation, sugammadex was observed to permanently bind with the rocuronium molecule (Welliver, 2013). The irreversible bond of sugammadex and rocuronium created a stable and inactive complex that was eliminated by the kidneys. Clinical trials have shown sugammadex to be exponentially faster in reversing rocuronium-induced block, when compared to neostigmine, due to the direct mechanism of action (Welliver, 2013).

Therefore, the purpose of this paper was to complete a systematic review to compare the administration of sugammadex versus neostigmine and time to re-establish normal muscular function, as evidenced by a TOF ratio of 0.9 .

Next, a review of the literature will be presented. 


\section{Literature Review}

The primary databases searched were CINHAL Plus with full text, PubMed, and the Cochrane Library. The key words used in the literature search were neuromuscular blockade, sugammadex, neostigmine, and rocuronium. The key words were searched separately and combined to generate results over a period of ten years, from 2008- 2018.

\section{Neuromuscular Junction Anatomy \& Physiology}

The nerves of the peripheral nervous system regulate skeletal muscle contraction and relaxation. The anatomical region where the nerve and skeletal muscle synapse is referred to as the neuromuscular junction (NMJ). The NMJ is comprised of three major structural components: the pre-synaptic nerve, synaptic cleft, and the postsynaptic muscle membrane. Acetylcholine (ACh) is the chemical transmitter that is responsible for communication between the pre-synaptic nerve and the postsynaptic muscle membrane. An action potential causes depolarization of the pre-synaptic nerve, releasing ACh molecules into the synaptic cleft. ACh diffuses across the cleft to the postsynaptic muscle membrane, specifically the motor end plate, where it binds to the muscle's nicotinic acetylcholine receptor (nAChR) (Plummer-Roberts, Trost, Collins, \& Hewer, 2016).

The muscle's nAChR is a complex composed of five subunits: two alpha $(\alpha)$ subunits, and one of each: beta $(\beta)$, delta $(\delta)$, and epsilon $(\varepsilon)$ subunits. These subunits are organized cylindrically to form a transmembrane channel. When ACh occupies each of the $\alpha$-subunits, the nAChR undergoes a conformational change opening the channel, allowing sodium and calcium influx, and potassium efflux in the skeletal muscle 
(Plummer-Roberts et al., 2016). Sodium entry into the skeletal muscle activates the muscle's sarcoplasmic reticulum to release calcium and induce skeletal muscle contraction.

Acetylcholinesterase is an enzyme that is present at the motor end plate of the skeletal muscle membrane. Once ACh is inactivated by acetylcholinesterase at the nAChR, skeletal muscle relaxation ensues. This enzyme hydrolyzes ACh into its inactive constituents: acetate and choline. Acetate and choline constituents are recycled to synthesize subsequent ACh molecules to allow for ensuing skeletal muscle contraction (Plummer-Roberts et al., 2016).

\section{Neuromuscular Blockade}

Neuromuscular blockade, also referred to as muscle relaxation, occurs when transmission of the nerve impulse at the NMJ is blocked, inhibiting skeletal muscle contraction. NMBAs exert their effect by altering the ability of the chemical transmitter ACh to bind to the muscle membrane's nAChR. There are two classes of NMBAs that can be used to accomplish muscle relaxation: depolarizing agents and non-depolarizing agents (Kirkland, 2013).

Use of an NMBA may be required to facilitate tracheal intubation or inhibit spontaneous, reflexive movements to safely complete an operation. The depth and length of muscle relaxation required is dependent on the surgical procedure performed. For example, if skeletal muscle tone is to affect operating conditions and surgical outcomes, then muscle relaxation with the use of NMBAs would be beneficial (Kirkland, 2013). One commonly cited surgical procedure requiring muscle relaxation is laparoscopic surgery in an area near the patient's diaphragm. Cited benefits of paralysis for this type 
of procedure include: immobility, enhanced vision, and improved access to the surgical field (Kirkland, 2013).

Non-depolarizing agents. Non-depolarizing NMBA's work by competitively binding one of the two $\alpha$-subunits on the muscle's nAChR, a mechanism referred to as “antagonizing". Blockade of one $\alpha$-subunit on the nAChR, prevents the neurotransmitter ACh from binding the required two $\alpha$-subunits to induce skeletal muscle contraction. This mechanism prevents depolarization at the skeletal muscle's motor end plate, resulting in muscle paralysis (Plummer-Roberts et al., 2016).

Non-depolarizing agents are further classified into two categories: benzylisoquinoline and aminosteroid compounds. The major difference between these drug categories is their pharmacokinetic profile. Benzylisoquinoline blocking agents are eliminated by Hoffmann elimination, which relies on body temperature and $\mathrm{pH}$ to metabolize and eliminate the agents. Aminosteroid blocking agents rely on hepatic and renal systems for metabolism and elimination. Benzylisoquinoline blocking agents may be preferred in patients with liver or renal dysfunction, while aminosteroid blocking agents may be preferential in asthmatic patients due to the lack of histamine release. Commonly used agents in the aminosteroid class of NMBA's include: pancuronium, rocuronium, and vecuronium (Papathanas \& Killian, 2017).

\section{Residual Neuromuscular Blockade}

The presence of skeletal muscle weakness after administration of a neuromuscular blocking agent is referred to as residual neuromuscular blockade (RNMB). Wiatrowski, Martini, Flanagan, Freeman, and Sloan (2018) identified that RNMB occurs postoperatively in $20-60 \%$ of patients who receive non-depolarizing NMBAs. The 
sequelae that result from RNMB include airway obstruction, impaired oxygenation and ventilation, hypoxemia resulting in the need for re-intubation, as well as the risk for aspiration due to impaired pharyngeal reflexes (Wiatroswki et al., 2018). These complications are serious, potentially life-threatening, and increase patient perioperative morbidity and mortality.

\section{Measures of monitoring neuromuscular blockade}

Administration of NMBAs requires vigilant assessment and observation by the anesthesia provider. The practice standard set forth by the American Association of Nurse Anesthetists (AANA) requires monitoring of neuromuscular response to NMBAs, assessment of the depth of blockade and assessment of skeletal muscle recovery (AANA, 2013). An excessive dose of a NMBA may cause residual skeletal muscle paralysis postprocedure, while an inadequate dose may result in unanticipated movement during critical portions of a surgical procedure (Nagelhout \& Plaus, 2014).

Experts endorse routine monitoring of neuromuscular blockade as a cornerstone of patient safety. Monitoring neuromuscular blockade intraoperatively helps guide the anesthesia provider in determining the depth of muscle relaxation, while avoiding overparalysis and resulting post-operative residual paralysis (Nagelhout \& Plaus, 2014).

Anesthesia providers use a combination of clinical, qualitative, and quantitative measures to determine recovery from neuromuscular blockade.

Qualitative measures. Qualitative monitoring is a form of subjective monitoring, which allows the anesthesia provider to assess the degree of blockade by a visual and/or tactile response to a stimulus. Qualitative measures are commonly assessed by direct clinical tests or use of an electrical stimulus from a peripheral nerve stimulator (PNS) 
(Mathias \& Bernardis, 2012). A peripheral nerve stimulator device can deliver various patterns of electrical impulses to a patient's nerve through skin electrodes to evoke a predictable muscle contraction (Nagelhout \& Plaus, 2014). Common neuromuscular monitoring tests that are used to produce a predictable, visible pattern of muscle contraction include: single twitch, train-of-four, double-burst simulation, tetanus, and post-tetanic count (Appendix A).

Train-of-four (TOF) monitoring. TOF monitoring exerts a series of four separate electrical impulses 0.5 seconds apart at a frequency of two hertz $(\mathrm{Hz})$ for two seconds. This stimulus produces four observable muscle twitches, which are referred to as $T_{1}$ through $\mathrm{T}_{4}$, respectively (Nagelhout \& Plaus, 2014). Administration of a nondepolarizing NMBA will result in progressive diminution of the twitch response to the electrical stimulus, a concept known as fade. The fourth twitch $\left(\mathrm{T}_{4}\right)$ will disappear first, as the neuromuscular block deepens there will be disappearance of the preceding twitches; $T_{3}, T_{2}$, and $T_{1}$, respectively. Twitches cannot be elicited when $100 \%$ paralysis is achieved (Nagelhout \& Plaus, 2014).

Of importance to the anesthesia provider is the comparison of the last twitch $\left(\mathrm{T}_{4}\right)$ to the first twitch $\left(T_{1}\right)$. Subjectively comparing $T_{4}$ and $T_{1}$ allows a determination of a train-of-four ratio (TOFR), which assists the provider in determining the level of neuromuscular blockade present. A TOFR of 0.9 or greater is the accepted standard to determine adequate reversal from neuromuscular blockade, indicating that the fourth twitch $\left(\mathrm{T}_{4}\right)$ response is $90 \%$ of the first twitch $\left(\mathrm{T}_{1}\right)$. Qualitatively measuring TOF may result in inter-rater variance and a reliable TOFR of 0.9 may not always be achieved (Wiatrowski et al., 2018). 
Clinical Tests. Clinical tests are subjective measurements of patient strength to determine whether RNMB is evident. For example, the 5-second head lift test instructs the patient to lift their head from a pillow for a consecutive five seconds. Recent data supports a patient can adequately complete this task despite a TOFR of $0.45-0.75$ (Wiatrowksi et al., 2018). Another traditionally used clinical test is forced vital capacity (FVC), which is the maximum amount of air a person can exhale after a maximum inhalation. A person with a TOFR of 0.5 can adequately complete a forced vital capacity breath (Wiatrowski et al., 2018). The use of clinical tests to determine presence of neuromuscular blockade is not adequate to reliably ascertain a TORF of 0.9 (Wiatrowski et al. 2018).

Quantitative measures. Quantitative monitoring allows an objective assessment to be made by the anesthesia provider. Quantitative monitoring utilizes the same patterns of stimulation from a PNS and furthermore, couples the stimulus to a displacement transducer. The displacement transducer acts as a movement measuring device and computes a numerical value. Quantitative monitoring can be accomplished by using acceleromyography (AMG), electromyography (EMG), mechanomyography (MMG), and kinemyography (KMG) (Nagelhout \& Plaus, 2014). Mechanomyography measures the force of isometric contraction of a muscle after nerve stimulation. Data analyzed from MMG devices assisted in the development of the gold standard TOFR of 0.9 to indicate adequate return of neuromuscular function; however, due to the cumbersome setup of MMG devices their use outside of research is minimal (Wiatrowski et al., 2018). In clinical practice, $\mathrm{AMG}$ devices are commonly used. AMG measures isotonic contraction of muscle tissue in response to nerve stimulation, specifically a TOF 
stimulation pattern at the level of the ulnar nerve (Wiatrowski et al., 2018). The ulnar nerve innervates the adductor pollicis muscle of the thumb, and when stimulated causes the thumb to adduct. This site is best for measuring recovery from neuromuscular blockade due to the pharmacodynamics of NMBAs and easy accessibility to providers. Coupling this stimulation to a displacement transducer allows an output to be computed to reflect an objective measure of the TOFR, and ascertainment of a TOFR of 0.9 .

\section{Reversal Agents}

The risk of residual neuromuscular blockade and resulting skeletal muscle weakness drives the practice for administering reversal agents. The ideal reversal agent would provide rapid, complete, and reliable reversal with minimal side effects (Welliver, 2013). Traditionally, a class of medications called anticholinesterases have been used to reverse neuromuscular blockade. Anticholinesterase agents require a small degree of spontaneous skeletal muscle recovery to be efficacious in antagonizing muscle paralysis. Although commonly used in practice, anticholinesterase agents are not without side effects. Co-administration of anticholinergics are used to reverse these untoward effects of anticholinesterases (Nagelhout, 2013).

Research over the last decade has introduced a new class of medications, selective relaxant-binding agents (SRBAs), for reversal of neuromuscular blockade. Sugammadex, a SRBA, has shown to be efficacious in reversing neuromuscular blockade regardless of depth of paralysis with minimal adverse effects. Clinical trials have suggested that time to a TORF of 0.9 is decreased by using sugammadex as a reversal agent (Welliver, 2013).

Anticholinesterases. Anticholinesterases are a class of medications that work to increase the amount of ACh available at the NMJ through blockade of the enzyme 
acetylcholinesterase. Allowing ACh to accumulate increases the probability that it will preferentially bind to the $\alpha$-subunits on the nAChR, initiating skeletal muscle recovery (Plummer-Roberts et al., 2016). The mechanism in which anticholinesterases exert their effect is primarily through antagonism of residual non-depolarizing NMBA molecules. Neostigmine is a commonly used anticholinesterase agent for reversal of neuromuscular block.

Despite neostigmine's mechanism of action, if the NMJ is highly concentrated by the NMBA, increasing ACh molecules may be inadequate to antagonize the NMBA (Jones, Caldwell, Brull, \& Soto, 2008). Anticholinesterase agents are efficacious only when a small degree of endogenous skeletal muscle recovery is present, therefore prudent TOF monitoring by the anesthetist is warranted to assess for twitch responses. If $100 \%$ blockade is present at the $\mathrm{NMJ}$, neostigmine is an ineffective antagonist; and may subsequently result in paradoxical muscle weakness if additional doses are administered when $100 \%$ of acetylcholinesterase is inhibited (Plummer-Roberts et al., 2016).

$\mathrm{ACh}$ is the primary chemical messenger in the parasympathetic nervous system. In addition to activating the $\mathrm{nAChR}$ in the $\mathrm{NMJ}, \mathrm{ACh}$ can stimulate muscarinic receptors throughout the body. Activating muscarinic receptors induces effects such as: bradycardia, bronchoconstriction, increased airway secretions, and increased gastric motility (Nagelhout, 2013). To prevent the previously stated effects, an anticholinergic medication is administered concurrently to block activation of muscarinic receptors. Anticholinergic medications are not without side effects, which may include: blurred vision, dry mouth, urinary retention, and tachycardia (Nagelhout, 2013). A commonly administered anticholinergic agent is glycopyrrolate. 
Pairing of neostigmine and glycopyrrolate is used in clinical anesthesia to reverse neuromuscular blockade. The pairing of neostigmine and glycopyrrolate is preferential as the two agents have a similar onset and duration of action. One of the main limitations of this traditional method of reversal is that the time to reliably produce a TOFR of 0.9 within 30 minutes varies (Welliver, 2013).

Selective relaxant-binding agents. Sugammadex is the only available selective relaxant-binding agent. The structure of sugammadex is a modified $\gamma$-cyclodextrin, resembling the shape of a hollowed cone. The exterior of the cone is hydrophilic, and the interior is hydrophobic. Hydrophobic interactions within the cone allow the steroidal NMBAs (rocuronium, vecuronium, and pancuronium) to be encapsulated by sugammadex in a 1:1 ratio. The rocuronium-sugammadex complex has the highest association rate and does not easily dissociate; for every 30 million complexes formed, only one complex dissociates (Naguib, 2015). By encapsulating the steroidal NMBAs, sugammadex leaves them unable to antagonize the nAChR (Plummer-Roberts et al., 2016).

The mechanism sugammadex uses to encapsulate the rocuronium molecule is independent of enzyme systems and receptors in the body; therefore, sugammadex does not require co-administration of other pharmacologic agents (Naguib, 2015). Due to the high affinity of sugammadex and rocuronium, clinical studies have shown that reversal of profound rocuronium-induced neuromuscular blockade is possible despite the lack of endogenous muscle recovery (Naguib, 2015). The advantages of sugammadex include: reversal of any level of blockade within 3 minutes of administration when dosed appropriately, and lack of muscarinic side effects (Plummer-Roberts et al., 2016). 


\section{Studies Evaluating Blockade Reversal}

Acceleromyography using a train-of-four (TOF) mode of stimulation is a consistent method of measurement of neuromuscular blockade across randomized control trials. TOF stimulation generates four electrical impulses over 2 seconds, which evokes muscle twitching. The mechanism of acceleromyography converts the measured accelerations into electrical signals (Kirkland, 2013). The number, height, and acceleration of the four muscle twitches is recorded. Prior to administering any NMBA, the four twitches should be of equal height, yielding a TOFR of 1.0. Non-depolarizing NMBAs cause twitch height to fade as block depth increases, which decreases the TOFR (Kirkland, 2013). A TOFR of 0.9 is considered the gold standard of adequate reversal of neuromuscular block.

General surgical procedures. Jones et al. (2008) conducted a phase III, multicenter, randomized control trial in the United States, comparing the use of sugammadex versus neostigmine for reversal of profound rocuronium-induced neuromuscular blockade. This study included a sample size of 74 participants, American Society of Anesthesiologists (ASA) class I-IV, at least 18 years of age, undergoing an elective surgical procedure under general anesthesia in the supine position. Participants were randomized to receive either $4.0 \mathrm{mg} / \mathrm{kg}$ sugammadex $(\mathrm{n}=37)$, or $0.7 \mathrm{mg} / \mathrm{kg}$ neostigmine plus $0.014 \mathrm{mg} / \mathrm{kg}$ glycopyrrolate $(\mathrm{n}=37)$.

After induction of general anesthesia, baseline neuromuscular function was established using acceleromyography. Subsequently, participants received $0.6 \mathrm{mg} / \mathrm{kg}$ of rocuronium for tracheal intubation and maintenance doses of $0.15 \mathrm{mg} / \mathrm{kg}$ rocuronium as required by the surgical procedure. When surgical conditions permitted, participants 
were allowed to spontaneously recover until 1-2 post-tetanic counts (PTCs) were present, indicating presence of profound neuromuscular blockade (Reference Appendix A). At 12 PTCs a single dose of $4.0 \mathrm{mg} / \mathrm{kg}$ sugammadex or $0.7 \mathrm{mg} / \mathrm{kg}$ neostigmine plus $0.014 \mathrm{mg} / \mathrm{kg}$ glycopyrrolate was administered. Neuromuscular monitoring via acceleromyography was maintained on each participant throughout the trial until a TOFR of 0.9 was re-established (Jones et al., 2008).

Participants were assessed every 15 minutes after tracheal extubation until discharge from the post-anesthesia care unit (PACU). A blinded assessor conducted assessments including: level of consciousness, a 5 second head-lift, and general muscle weakness via a rating scale of 1 [extreme impairment] to 9 [no impairment], while monitoring for potential clinical signs of residual neuromuscular blockade (Jones et al., 2008). Participants who received sugammadex recovered to a TOFR of 0.9 within a geometric mean time of 2.9 minutes versus 50.4 minutes in participants who received neostigmine plus glycopyrrolate $(P<0.0001)$. Jones et al. (2008) concluded that profound rocuronium-induced neuromuscular blockade could be more reliably and rapidly reversed by sugammadex than neostigmine.

Blobner et al. (2010) conducted a quantitative, experimental, randomized control trial in Europe, comparing the efficacy of sugammadex and neostigmine for reversal of rocuronium-induced neuromuscular blockade. A sample size of 98 participants, at least 18 years of age, undergoing an elective surgical procedure were categorized into the ASA class I-III. Participants were randomized into either the interventional group, which received sugammadex $(n=49)$, or control group, which received neostigmine $(n=49)$. When the participants did not require neuromuscular blocking agents any longer, they 
were allowed to spontaneously recover until the appearance of a second twitch $\left(\mathrm{T}_{2}\right)$ on TOF stimulation. At $\mathrm{T}_{2}$ the dose of assigned medications was delivered: $2.0 \mathrm{mg} / \mathrm{kg}$ of sugammadex or $50 \mathrm{mcg} / \mathrm{kg}$ of neostigmine (with $10 \mathrm{mcg} / \mathrm{kg}$ of glycopyrrolate). In all participants, neuromuscular monitoring continued until recovery of the TOFR returned to 0.9. Upon arrival to the PACU, assessments were conducted of general muscle weakness, level of consciousness, and a 5 second head-lift test. Within five minutes of administration of the reversal agent, $98 \%$ of sugammadex patients had recovered to a TOFR of 0.9 , compared with $11 \%$ of neostigmine patients $(P<0.0001)$. In the neostigmine group, 101 minutes elapsed, before $98 \%$ of participants recovered to a TOFR of 0.9. In this experimental study, drug related adverse effects were considered mild to moderate, and there were no participants eliminated from the trial due to an adverse event.

Bariatric surgical procedures. Gaszynski, Szewczyk, and Gaszynski (2011) conducted a quantitative, prospective, experimental, randomized study comparing sugammadex and neostigmine for reversal of rocuronium-induced muscle relaxation in morbidly obese patients undergoing elective bariatric surgery. Pharmacologic alterations, specifically, delayed drug onset and peak of action, in most anesthetic drugs are observed in morbidly obese patients' due to a greater volume of distribution. The intent was to decrease time to recovery of neuromuscular function, measured by a TOF ratio of 0.9 , and prevent PORP complications. Gaszynski et al. (2011) calculated the dose of the reversal agent in their study by using patient's corrected body weight (CBW), instead of patient's ideal body weight. This calculation increased the amount of each reversal agent each patient received. Seventy patients were randomized into either a sugammadex 
intervention group $(n=35)$ or neostigmine control group $(n=35)$. The sugammadex group received $2 \mathrm{mg} / \mathrm{kg}$ of $\mathrm{CBW}$, and the neostigmine group received $0.05 \mathrm{mg} / \mathrm{kg}$ of $\mathrm{CBW}$ with concurrent administration of atropine $0.02 \mathrm{mg} / \mathrm{kg}$ of CBW.

At the end of surgery, when accelerometry TOF stimulation exhibited two twitches, study drugs were administered, and time was recorded. The mean time to neuromuscular recovery, as evidenced by a TOFR 0.9 , was two minutes in the sugammadex group and nine minutes in the neostigmine group. Ultimately, mean time to TOFR 0.9 was 3.5 times shorter in the sugammadex than the neostigmine group (Gaszynski et al., 2011). Statistical t-tests identified a $p$ value of $<0.05$ as a significant finding. There was a statistically significant difference in recovery to reestablish muscular function between sugammadex and neostigmine $(p<0.05)$. One episode of profound bradycardia was assessed in the neostigmine group after administration of the study drug (Gaszynski et al., 2011). This adverse effect could have been due to using CBW instead of ideal body weight.

Alsaeed,et al. (2017) conducted a prospective randomized trial in Saudi Arabia comparing reversal of rocuronium blockade with sugammadex $2 \mathrm{mg} / \mathrm{kg}$ of CBW versus two different dosages of neostigmine, $2.5 \mathrm{mg}$ and $5 \mathrm{mg}$. A sample size of 110 participants with a body mass index $(\mathrm{BMI})>40$, undergoing elective gastric sleeve (bariatric) surgery with general anesthesia were enrolled in this study. All participants were monitored intraoperatively with neuromuscular transmission monitoring (NMT). Randomization of participants into one of three groups was accomplished by use of sealed envelopes and a randomization table. At the completion of surgery PTCs and TOF count were recorded. The TOF count recorded immediately prior to the injection of the reversal agent in 
Groups A, B, and C, was 2 twitches, 1 twitch, and 1 twitch, respectively. Subsequently, Group A ( $\mathrm{n}=38$ ) received sugammadex $2 \mathrm{mg} / \mathrm{kg}$ of CBW, Group B $(\mathrm{n}=41)$ received neostigmine $2.5 \mathrm{mg}$, Group $\mathrm{C}(\mathrm{n}=31)$ received neostigmine $5 \mathrm{mg}$.

A timer was used to record the seconds until a TOFR of 0.9 was achieved. Group A achieved a TOFR of 0.9 in 210 seconds, Group B in 610 seconds, and Group C in 654 seconds (Alsaeed et al., 2017). Of note, the mean values for the BMI in each Group, A, B, and C, was 38, 46, and 46, respectively. Alsaeed et al. (2017) determined the time to reach a TOFR of 0.9 was significantly decreased in Group A versus Groups B and C ( $P$ $<0.05$ ), and therefore concluded that sugammadex reverses neuromuscular blockade induced by rocuronium more rapidly than neostigmine.

Laparoscopic surgical procedures. Laparoscopic surgical procedures often require deep neuromuscular blockade until the end of an operation. Geldner et al. (2012) conducted a study to compare recovery from different depths of rocuronium-induced neuromuscular blockade. Sugammadex was given during deep neuromuscular blockade, versus neostigmine administration at the reappearance of moderate blockade in patients undergoing laparoscopic surgery (Geldner et al., 2012).

Geldner et al. (2012) utilized a multicenter, quantitative, randomized, blinded, control trial in their research. Ten study sites were enrolled: three in Russia; four in Germany; two in Finland; and one in the UK. A total of 140 participants enrolled in the study were randomized to receive either $4 \mathrm{mg} / \mathrm{kg}$ of sugammadex to reverse deep neuromuscular blockade $(\mathrm{n}=70)$ or $50 \mathrm{mcg} / \mathrm{kg}$ of neostigmine, plus atropine $10 \mathrm{mcg} / \mathrm{kg}$ $(\mathrm{n}=70)$ to reverse moderate neuromuscular blockade. The efficacy variable was the elapsed time from reversal agent administration to recovery of the TOF ratio to 0.9 . 
Patients who received sugammadex recovered 3.4 times faster than patients who received neostigmine despite the differences in depth of neuromuscular blockade; recovery times of 2.4 minutes and 8.4 minutes, respectively. Times recorded from last dose of rocuronium to recovery were 13.3 minutes in the sugammadex group and 35.2 minutes in the neostigmine group (Geldner et al., 2012). Documentation of the last dose of rocuronium eliminated administration as being a confounding variable of causality between sugammadex and neostigmine time to reversal. ANOVA bivariate statistical analysis was utilized to determine statistical significances between the control and intervention group. Recovery times were statistically significant in supporting the time to reestablish neuromuscular function was decreased when sugammadex was administered for NMBA reversal (Geldner et al., 2012).

Next, the theoretical framework utilized for this systematic review will be discussed. 


\section{Theoretical Framework}

Systematic reviews and meta-analyses have become increasingly prevalent in health care due to their ability to compile important data which influences clinical practice guidelines and decision-making (Moher, Liberati, Tetzlaff, Altman, \& PRISMA Group, 2009). Critical content analysis and quality reporting of systematic reviews has been imperative due to the paramount influence systematic reviews have on clinical practice. To improve the quality reporting of systematic reviews, Moher et al. (2009) developed the Preferred Reporting Items for Systematic review and Meta-Analyses (PRISMA) statement, which allows the reader full transparency to assess the strengths and weaknesses of any systematic review. The PRISMA statement and Critical Appraisal Skills Programme (CASP) critical appraisal tool will be utilized to guide this systematic review.

The PRISMA statement consists of an explicit 27-item checklist (Appendix B), comprised of seven domains, which include: title, abstract, introduction, methods, results, discussion, and funding (Moher et al., 2009). The checklist sets forth the minimum set of criteria required for evidence-based research studies included in a systematic review (Moher et al., 2009). The PRISMA checklist ensured completeness of extracted data from each of the included randomized control trials.

The PRISMA statement also included a four-phase flow diagram (Appendix C), which was utilized to exhibit the selection process for study inclusion and exclusion in this systematic review. The product of the flow diagram provided a final number of eligible studies for inclusion. Together, the PRISMA checklist and flow diagram provided the framework for development of this systematic review. 
The critical appraisal tool employed to evaluate the studies in this systematic review was the 11-question assessment tool from the CASP of the Centre for EvidenceBased Medicine (Polit \& Beck, 2017). The first two questions of this appraisal tool screened whether the study being critically appraised possessed enough validity to continue reviewing (CASP, 2017). The subsequent questions stimulated systematic evaluation of the research. Additionally, each subsequent question provided prompts, designed to reinforce the importance of the question as it related to the research article (CASP, 2017). Once the studies proved to have valid results and relevance, the CASP tool provided an approach to critically appraise and conclude the usefulness of the findings (CASP, 2017).

The CASP tool assisted to determine the trustworthiness, results, and relevance of the research studies (CASP, 2017). The CASP tool, comprised of 11 questions, was answered by the researcher as "yes", "no", or "can't tell". The CASP tool examined: the validity of results, random assignment of participants, participant trajectory through the research project, "blinding" of treatments to assessors and participants, equal assortment and treatment, results and significance of the treatment effect, and benefit/risk ratio of the treatment (CASP, 2017) (Appendix E).

Next, the method section will be presented and discussed. 


\section{Method}

\section{Purpose}

The purpose of this paper was to complete a systematic review to compare the administration of sugammadex versus neostigmine and time to reestablish normal muscular function, as evidenced by a TOF ratio of 0.9 . The research question investigated was: Is there a difference in time to re-establish normal muscular function, as evidenced by a TOFR of 0.9 , when sugammadex versus neostigmine is administered?

\section{Inclusion/Exclusion Criteria}

Inclusion criteria consisted of randomized control trials conducted within the last ten years which included the following: adult surgical population (18 years of age or older); American Society of Anesthesiologist (ASA) Class I-IV patients; elective surgical procedures; use of rocuronium for neuromuscular blockade; use of TOF measurement to measure reversal agents; and use of sugammadex as a reversal agent and neostigmine as the comparative agent.

Exclusion criteria included: literature over ten years old; ASA class V patients; emergent cases; pediatric cases (less than 18 years of age); use of alternate tools to assess return of neuromuscular function; and use of other non-depolarizing steroidal NMBA's.

\section{Search Strategy}

The primary databases used for the literature search were PubMed, CINHAL with full text, and the Cochrane Library. An initial search of the term "neuromuscular blockade" was conducted in each database. The search was narrowed down further with the terms: "neostigmine", "sugammadex", and "rocuronium". The search was limited to randomized control trials from January 2007 to June 2018. Results were filtered to 
include articles written in English and then individually reviewed to determine if the criteria had been met for inclusion in this systematic review.

\section{Data Collection and Synthesis}

Articles were reviewed methodically, and each individual study was transferred into two data collection tables created by this author. Data collection tables were created and tailored to meet the focus of this systematic review. Data collected and displayed in table 1 included: site/sample, method/design, time to TOFR of 0.9 with sugammadex, and time to TOFR of 0.9 with neostigmine. Data collected and displayed in table 2 included: type of elective procedure, adverse events, results, and limitations (Appendix D).

Table 1 - Data Collection Tool 1

\begin{tabular}{|c|c|c|c|}
\hline Site/Sample & Method/Design & $\begin{array}{c}\text { Time to TOFR of } 0.9 \\
\text { with Sugammadex }\end{array}$ & $\begin{array}{c}\text { Time to TOFR of } 0.9 \\
\text { with Neostigmine }\end{array}$ \\
\hline & & & \\
\hline
\end{tabular}

Table 2 - Data Collection Tool 2

\begin{tabular}{|l|l|l|l|}
\hline Type of Elective Procedure & Adverse Events & Results & Limitations \\
\hline & & & \\
\hline
\end{tabular}

\section{Critical Appraisal Tools}

Critical appraisal of research allows the investigator to evaluate the findings in a systematic way and utilize findings to make clinical practice decisions. The CASP tool was utilized to critically appraise the randomized control trials to determine the credibility of the studies included in this systematic review. All 11 questions regarding fairness, equality, and randomization of participants; measured outcomes; generalizability 
of results; and risk-benefit analysis of trials were answered for each study to reach a comprehensive conclusion regarding the scientific integrity of the research (CASP, 2017) (Appendix E).

\section{Cross Analysis}

After individual analysis, all randomized control trials were cross analyzed to compare data. The cross-study analysis evaluated the similarities and differences between the time to return to a TOFR of 0.9 when sugammadex versus neostigmine was administered. Additionally, the type of surgical procedure was compared across studies to determine whether the type of surgery impacted the results. The information was recorded in the data collection table below (Table 3) (Appendix F).

Table 3 - Cross Study Analysis

\begin{tabular}{|c|c|c|c|}
\hline Author & $\begin{array}{c}\text { Time to TOFR of } 0.9 \text { with } \\
\text { Sugammadex }\end{array}$ & $\begin{array}{c}\text { Time to TOFR of } 0.9 \text { with } \\
\text { Neostigmine }\end{array}$ & $\begin{array}{c}\text { Type of Surgical } \\
\text { Procedure }\end{array}$ \\
\hline & & & \\
\hline
\end{tabular}

The data collection, critical appraisal and cross analysis results are reported in narrative format in this systematic review.

\section{Dissemination of Findings}

Findings from this systematic review were disseminated through a major paper and poster presentation. The optimal audience reached was student and certified registered nurse anesthetists, who would be able to translate these findings into clinical practice. Future research, including cost-analysis statistics, would be warranted to determine whether sugammadex versus neostigmine for reversal of rocuronium-induced neuromuscular blockade is cost-effective.

Next, the results section will be discussed. 


\section{Results}

The PRIMSA flow diagram (Appendix C), as well as the inclusion and exclusion criteria previously discussed, were utilized for selection of randomized control trials included in this systematic review. The PRISMA flow diagram exhibited below (figure 1.) displays the breakdown of the search strategy.

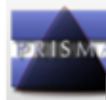

PRISMA 2009 Flow Diagram
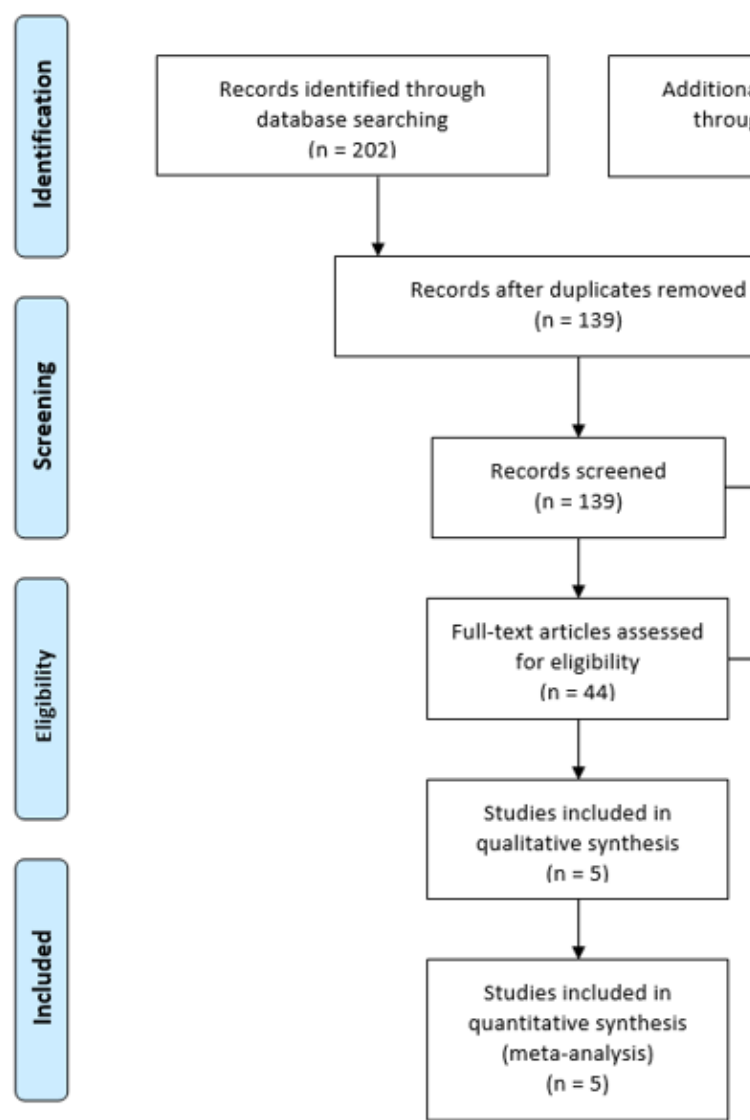

\section{Figure 1. PRISMA Flow Diagram}

The original search of the term "neuromuscular blockade" yielded 202 results. Of the 202 results, articles were screened for duplicates. Removal of duplicate research ceded 139 results for review. The additional terms "neostigmine", "sugammadex", and 
"rocuronium" were searched, which yielded 44 results for review. The titles and abstracts were evaluated for inclusion and exclusion criteria specific to this systematic review. The final five randomized control trials that met this systematic review's inclusion criteria were analyzed accordingly. Key information was extracted and recorded into the data collection tables in Appendix D. Additionally, the studies were critically appraised using the CASP checklist (Appendix E). The following information summarized the results obtained from the data collection tables.

The randomized control trial conducted by Wu et al. (2014) (Appendix D1) demonstrated efficacy between sugammadex $2 \mathrm{mg} / \mathrm{kg}$ vs. neostigmine $50 \mathrm{mcg} / \mathrm{kg}$ in patients 18-64 years old of Caucasian and Chinese descent, undergoing elective surgery. Patients were enrolled from February 2010 to September 2010 at ten various sites; six sites in China and four sites in Europe. Subjects included for enrollment were undergoing elective surgery with propofol anesthesia, and rocuronium for NMB. Additionally, subjects were ASA Class I - III and never have emigrated from their birth country. A total of 289 subjects were enrolled. The authors calculated a sample size of 115 Chinese subjects required to give a power of $95 \%$. Due to prior studies concluding efficacy in Caucasian subjects, the authors determined 30 Caucasian subjects per treatment group were required to give a power of $95 \%$. A central randomization system was utilized to assign treatment groups; the experimental group received sugammadex $2 \mathrm{mg} / \mathrm{kg}$ and the control group received neostigmine $50 \mathrm{mcg} / \mathrm{kg}+$ atropine $10-20 \mathrm{mcg} / \mathrm{kg}$. Anesthesia was induced and maintained with IV propofol for the elective surgical procedure. TOF baseline monitoring was recorded prior to the administration of rocuronium. Rocuronium $0.6 \mathrm{mg} / \mathrm{kg}$ was administered to facilitate tracheal intubation. 
Maintenance doses of $0.1-0.2 \mathrm{mg} / \mathrm{kg}$ were administered as required throughout the anesthetic. Toward the conclusion of surgery, at the reappearance of a $T_{2}$ twitch, the experimental group received sugammadex $2 \mathrm{mg} / \mathrm{kg}$ and the control group received neostigmine $50 \mathrm{mcg} / \mathrm{kg}+$ atropine to reverse rocuronium-induced neuromuscular blockade. Following administration of reversal agents, the time to recover a TOF ratio of 0.9 was recorded. The authors found that sugammadex $2 \mathrm{mg} / \mathrm{kg}$ provided rapid reversal of rocuronium-induced neuromuscular blockade when compared with neostigmine in both Chinese and Caucasian subjects ( $p$ value of 0.0001 ). Chinese subjects who received sugammadex recovered to a TOF ratio of 0.9 in 1.6 minutes versus 9.1 minutes in Chinese subjects who received neostigmine. Caucasian subjects recovered to a TOF ratio of 0.9 in 1.4 minutes and 6.7 minutes after receiving sugammadex and neostigmine, respectively.

The study demonstrated (Appendix D1) there was a significantly faster time to recover to a TOF ratio of 0.9 in both Chinese and Caucasian subjects who received sugammadex $2 \mathrm{mg} / \mathrm{kg}$. Adverse events reported included: bradycardia and hypersensitivity reactions to the reversal agents. Of the eleven reported cases of bradycardia, ten of the cases used neostigmine, while only one Chinese subject experienced bradycardia with sugammadex. Hypersensitivity reactions were reported in ten Chinese subjects, seven received sugammadex, and three received neostigmine. The authors identified that interethnic differences were likely to be multifactorial, and no obvious limitations were reported in the study.

Critical analysis of the Wu et al. (2014) study using the CASP checklist (Appendix E1) revealed all except two of the critical appraisal questions were scored as 
"yes". The first question scored as "no" regarded whether patients, health workers, and study personnel were 'blind' to treatment. In Wu et al. (2014), patients who consented to study enrollment were blinded to the treatment received. The study investigators were blinded to treatment, however, the anesthesia provider administering the drug was not blinded. The second question scored as "no" regarded whether the groups were similar at the start of the trial. Of the 289 subjects enrolled, 230 Chinese subjects were divided into two treatment groups, and 59 Caucasian subjects were further divided into two treatment groups. Gender composition of the groups was not classified by the authors, however racial differences were purposefully categorized at the inception of this study. Aside from these two questions, the trial clearly addressed a focused issue, randomized the assignment of patients to treatments, and properly accounted for all patients at the study's conclusion. All patients enrolled in the study were treated equally.

The next randomized control trial by Woo et al. (2013) (Appendix D2) was conducted to evaluate the efficacy of rocuronium-induced neuromuscular blockade reversal in Korean patients when sugammadex versus neostigmine was administered as the reversal agent. The study was a randomized, parallel-group, active-controlled, safety assessor-blinded phase IV study, conducted at seven sites in the Republic of Korea. Enrollees were of Korean descent, ASA class I-III, undergoing an elective surgical procedure under general anesthesia using rocuronium for NMB. A sample size of 128 subjects undergoing elective surgery were randomized on a 1:1 basis to receive either sugammadex $2 \mathrm{mg} / \mathrm{kg}$ or neostigmine $50 \mathrm{mcg} / \mathrm{kg}+$ glycopyrrolate $10 \mathrm{mcg} / \mathrm{kg}$. The authors determined a sample size of 50 Korean subjects per treatment group would be required to provide a power of $95 \%$, testing at a significance level of 0.05 . Anesthesia was induced 
with IV propofol and maintained with inhalational sevoflurane. Neuromuscular monitoring was established, subsequently rocuronium $0.6 \mathrm{mg} / \mathrm{kg}$ was administered to facilitate endotracheal intubation. Maintenance doses of rocuronium $0.1-0.2 \mathrm{mg} / \mathrm{kg}$ were administered as required throughout the anesthetic. During the conclusion of surgery, at the appearance of a $\mathrm{T}_{2}$ twitch, a solitary dose of sugammadex $2 \mathrm{mg} / \mathrm{kg}$ or neostigmine $50 \mathrm{mcg} / \mathrm{kg}+$ glycopyrrolate was administered to reverse neuromuscular blockade. Time elapsed from administration of reversal agent to recovery of a TOF ratio of 0.9 was recorded. The authors concluded mean time to recover a TOF ratio of 0.9 was 1.8 minutes in Korean subjects who received sugammadex, and 14.8 minutes in subjects who received neostigmine $(p<0.0001)$. Treatment related adverse events reported were of mild-to-moderate intensity. Four subjects who received sugammadex had reactions that included: bradycardia $(n=1)$ and headache $(n=3)$. Six subjects who received neostigmine reported headache $(n=2)$, nausea $(n=1)$, recurrence of NMB $(n=1), \operatorname{rash}(n=1)$, and hypotension $(n=1)$. The authors did not report limitations of the study.

Critical appraisal of the Woo et al. (2013) study (Appendix E2) identified all subjects were randomized into one of two treatment groups to receive either sugammadex or neostigmine, however the specific method utilized for randomization was not disclosed by study investigators. All questions except one, were scored as "yes" on the CASP tool. The single question that scored "no" addressed whether patients, health workers, and study personnel were 'blind' to treatment. Patients and study investigators were blinded to treatment. The anesthesiologist administering either sugammadex or neostigmine was not blinded, however was prohibited from revealing the assigned treatment group to study investigators. Both treatment groups were similar at the start of the trial, and the 
trial addressed a clearly focused issue. All subjects that participated in the study were treated equally throughout and properly accounted for at its conclusion.

In the study by Gaszynski et al. (2011) (Appendix D3), researchers evaluated the efficacy of neostigmine versus sugammadex for reversal of rocuronium-induced muscle relaxation. Seventy morbidly obese patients $(\mathrm{BMI}>40)$ undergoing an elective bariatric surgical procedure were included in this single center study performed at the Medical University of Lodz, Poland. Envelopes were prepared by a study investigator and used for participant randomization. The experimental group was composed of 35 subjects who received sugammadex $2 \mathrm{mg} / \mathrm{kg}$ of $\mathrm{CBW}$ and the control group comprised of 35 subjects who received neostigmine $50 \mathrm{mcg} / \mathrm{kg} \mathrm{CBW}+$ atropine $0.02 \mathrm{mg} / \mathrm{kg} \mathrm{CBW}$. Both groups were induced using IV propofol in $1.5-2 \mathrm{mg} / \mathrm{kg} \mathrm{CBW}$ doses and maintained with an inhalational desflurane, oxygen, and air mixture. Baseline TOF monitoring was obtained, then neuromuscular blockade was induced with rocuronium $1 \mathrm{mg} / \mathrm{kg}$ of CBW to facilitate tracheal intubation. If the TOFR spontaneously recovered to 1.0 during surgery, two additional rocuronium doses of $0.06 \mathrm{mg} / \mathrm{kg} \mathrm{CBW}$ could be administered. At the conclusion of surgery at the reappearance of a $T_{2}$ twitch, either sugammadex $2 \mathrm{mg} / \mathrm{kg}$ CBW or neostigmine $50 \mathrm{mcg} / \mathrm{kg}+$ atropine $0.02 \mathrm{mg} / \mathrm{kg} \mathrm{CBW}$ were administered based on participant randomization. Time elapsed from administration of reversal agent to a TOFR of 0.9 was recorded. Patients who received sugammadex recovered to a TOFR of 0.9 in a mean time of 2 minutes and 44 seconds, while patients who received neostigmine recovered in a mean time of 9 minutes and 37 seconds. The authors reported, with significance, that recovery to a TOFR of 0.9 was 3.5 times faster in patients who received 
sugammadex $(p<0.05)$. Limitations of this study were the small number of participants which has limited application to clinical outcomes.

Critical appraisal of the Gaszynski et al. (2011) study (Appendix E3), showed all but two of the CASP questions were scored as "yes". The trial addressed a clearly focused issue between two similar groups. Additionally, all subjects that participated in the study were treated equally throughout and properly accounted for at its conclusion. The first question scored as "no" was whether patients, health workers, and study personnel were 'blind' to treatment. Patients and study investigators were blinded to treatment. The anesthesia provider administering the reversal agent was not blinded to treatment. The second question scored as "no" regarded the precision of the estimate of the treatment effect. The authors failed to clearly identify the sample size required to provide and report a power analysis.

Illman et al. (2011) (Appendix D4) evaluated time to achieve a TOFR of 0.9 when sugammadex $2 \mathrm{mg} / \mathrm{kg}$ versus neostigmine $50 \mathrm{mcg} / \mathrm{kg}$ was administered as the reversal agent for rocuronium-induced neuromuscular blockade. Fifty subjects were enrolled at two University hospitals in Finland. Subjects were 18-70 years of age, ASA Class I - IV, undergoing elective surgery under general anesthesia. The authors identified twentythree patients were required in each treatment group to give a power of $90 \%$, testing at a significance level of 0.05. Exclusion criteria included significant renal, hepatic, or ventilatory dysfunction, BMI $>32.5$, pregnancy, patients with muscular dystrophies, and patients already on medications known to interfere with neuromuscular transmission.

General anesthesia was induced according to usual practice of the study center with IV propofol and an IV opioid. Rocuronium, 0.6-1 mg/kg, was administered based on 
clinical factors, duration of surgery, and facilitation of tracheal intubation. Anesthesia was maintained using an inhalation agent (either sevoflurane or desflurane) and opioids. Neuromuscular monitoring was initiated using TOF stimulation. Additional rocuronium was administered in 5-10mg doses as clinically necessary. At the conclusion of surgery, computer-generated sealed envelopes were utilized to randomly assign patients to receive either neostigmine $50 \mathrm{mcg} / \mathrm{kg}+$ glycopyrrolate $10 \mathrm{mcg} / \mathrm{kg}$ or sugammadex $2 \mathrm{mg} / \mathrm{kg}$. The reversal agent was prepared by a study nurse and administered when the anesthesiologist visualized a $\mathrm{T}_{2}$ twitch on TOF stimulation. The anesthesiologist remained blinded to the reversal agent administered by the study nurse. The time elapsed between a $T_{2}$ twitch and recovery to a TOFR of 0.9 was recorded by study investigators. Mean time to achieve a TOFR of 0.9 after administration of sugammadex and neostigmine + glycopyrrolate was $1.7 \pm 0.7$ minutes and $13.3 \pm 5.7$ minutes, respectively. The results from Illman et al. (2011) concluded time to recover a TOFR of 0.9 was significantly shorter when sugammadex $2 \mathrm{mg} / \mathrm{kg}$ was administered $(P<0.001)$.

The results of this study support the use of sugammadex as a faster and more reliable reversal agent than neostigmine. However, some limitations have been identified in the Illman et al. (2011) study. The use of 2 different volatile agents and 3 different opioids may be regarded as a limitation due to varying synergistic effects of the anesthetic agents. Additionally, the percent of inspired volatile agent was not reported, which could influence the degree of skeletal muscle relaxation.

Critical appraisal of this study (Appendix E4) shows all critical appraisal questions were scored as "yes". All participants were properly accounted for at the trial's 
conclusion. Patients, health workers, and study personnel were blinded to the treatment. Both groups were treated equally, and all clinically important outcomes were considered. Blobner et al. (2010) (Appendix D5) included ninety-eight patients undergoing elective surgery, in a randomized control trial to evaluate efficacy of sugammadex versus neostigmine for reversal of rocuronium-induced neuromuscular blockade. This study included thirteen sites in Europe. The authors identified that to have a power of $95 \%$ testing at a significance level of 0.05 , a total of 46 patients would have to be enrolled in each group. Patients enrolled were at least 18 years old, ASA class I-III, undergoing general anesthesia. Patients were excluded if they were an expected difficult intubation, had known renal or hepatic dysfunction, or a known contraindication to the medications used during the study.

Ninety-eight patients were randomized into two groups to receive either sugammadex $2 \mathrm{mg} / \mathrm{kg}$ or neostigmine $50 \mathrm{mcg} / \mathrm{kg}+$ glycopyrrolate $10 \mathrm{mcg} / \mathrm{kg}$. Anesthesia was induced with IV propofol, maintained with inhalational sevoflurane, and opioids were supplemented during the anesthetic as clinically indicated. Baseline TOF monitoring was obtained, subsequently rocuronium $0.6 \mathrm{mg} / \mathrm{kg}$ was administered to facilitate tracheal intubation and abolish successive twitch responses. Maintenance doses of $0.1-0.2 \mathrm{mg} / \mathrm{kg}$ of rocuronium were administered during the anesthetic as clinically indicated. When neuromuscular blockade was no longer required, patients were allowed to spontaneously recover to a $\mathrm{T}_{2}$ twitch on TOF stimulation. At the appearance of a $\mathrm{T}_{2}$ twitch, sugammadex $2 \mathrm{mg} / \mathrm{kg}$ or neostigmine $50 \mathrm{mcg} / \mathrm{kg}+$ glycopyrrolate $10 \mathrm{mcg} / \mathrm{kg}$ was administered. Blobner et al. (2010) concluded patients who received sugammadex 
recovered in a significantly shorter amount of time than patients who received neostigmine $(P<0.0001), 1.5$ minutes and 18.6 minutes, respectively.

Critical appraisal (Appendix E5) of the Blobner et al. (2010) study revealed all critical appraisal questions were scored as "yes" except for one that addressed whether patients, health workers, and study personnel were 'blind' to treatment. The participants were blinded to treatment, as were the study personnel. The anesthesia provider administering the reversal agent was not blind to treatment. The relative distribution of surgical procedures was similar, and both groups were treated equally. All participants were properly accounted for at the study's conclusion.

\section{Cross Analysis}

The randomized control trials included in this systematic review were cross analyzed (Appendix F). The cross analysis of these studies compared time to establish a TOFR of 0.9 with sugammadex, time to establish a TOFR of 0.9 with neostigmine, and the type of elective surgical procedure which required general anesthesia.

All the randomized control trials included in this systematic review evaluated the efficacy of sugammadex versus neostigmine for reversal of rocuronium-induced neuromuscular blockade. All randomized control trials used general anesthesia as the primary anesthetic. All surgeries were elective, performed on ASA class I-IV patients. Patients with co-morbidities that could potentially affect the outcomes of the study, such as renal or hepatic dysfunction were excluded.

Although surgical procedures varied or were not specifically identified, results were not impacted based on the type of surgery performed. Wu et al. (2014) did not specify the type of surgical procedure, however the authors identified that the surgery 
was elective. Woo et al. (2013) investigated patients undergoing elective operations of the ear, nose, and larynx (48\%), gynecologic (18\%), digestive system and spleen (17\%). Gaszynski et al. (2011) evaluated patients undergoing elective bariatric surgery. Illman et al. (2011) did not specify the type of elective surgical procedure. Blobner et al. (2010) studied patients undergoing a variety of elective operations, including: ears, nose, and larynx (19\%); teeth, jaws, mouth, and pharynx (16\%); digestive system and spleen (16\%); urinary system, male genital organs, and retroperitoneal space (13\%); musculoskeletal system (12\%); female genital organs (9\%); endocrine system (7\%); eye and adjacent structures (4\%); and mammary gland surgery (2\%). The cross-study analysis results supported the hypothesis that sugammadex $2 \mathrm{mg} / \mathrm{kg}$ would be a reliably faster acting agent to reverse moderate levels of rocuronium-induced neuromuscular blockade, when compared to neostigmine (Appendix F). Mild-to-moderate adverse effects of both sugammadex and neostigmine were reported, however the benefits of quickly and reliably reversing neuromuscular blockade outweighed the associated risks.

Next, the summary and conclusions section will be presented. 


\section{Summary and Conclusion}

A comprehensive understanding of the neuromuscular junction and mechanism of action of varying muscle relaxants has been a cornerstone of modern anesthesia practice. A thorough literature review was conducted to highlight the importance of using neuromuscular blocking agents to facilitate safe surgical procedures, as well as the importance of properly reversing these agents. Wiatrowski et al. (2018) identified residual neuromuscular blockade occurs postoperatively in $20-60 \%$ of patients who received non-depolarizing NMBAs. Detrimental consequences that could potentially result include: aspiration from impaired reflexes, airway obstruction, and impaired oxygenation and ventilation requiring re-intubation (Wiatrowski et al., 2018).

Assessment of neuromuscular blockade intraoperatively has been a standard of nurse anesthesia practice (AANA, 2013). Various clinical assessments have been utilized to determine adequate neuromuscular recovery; however, the gold standard of recovery remains a TOF ratio of 0.9 as measured by AMG. Nagelhout (2015) identified one of the main limitations of using cholinesterase inhibitors for reversal was the inability to produce a consistent and reliable TOFR of 0.9 within 30 minutes. Naguib (2015) cited advantages of sugammadex to include reversal of any level of blockade within 3 minutes of administration, lack of muscarinic side effects, and independence of enzyme systems and receptors in the body. Review of the literature warranted the need for this systematic review to determine the most reliable and consistent reversal agent of moderate levels, evidenced by a $T_{2}$ twitch, of rocuronium-induced neuromuscular blockade.

The purpose of this systematic review was to assess the efficacy of neostigmine versus sugammadex for reversal of moderate levels of rocuronium-induced 
neuromuscular blockade in adult patients undergoing an elective surgery under general anesthesia. Pubmed, CINHAL with full text, and the Cochrane Library databases were searched to find relevant articles. The PRISMA checklist and flow diagram was utilized to exhibit the selection process for study inclusion.

After development of inclusion and exclusion criteria, a total of five studies were selected as meeting criteria for inclusion in this systematic review. Each study was thoroughly analyzed to allow extraction of pertinent data for summarization in data collection tables. Following data extraction, the five studies were critically appraised utilizing the CASP checklist. An analysis across studies, which focused on the type of surgical procedure, and time to obtain a TOF ratio of 0.9 in both the control and experimental groups was conducted.

All five studies included in this systematic review identified that sugammadex, when compared to neostigmine, more reliably and consistently reversed moderate rocuronium-induced neuromuscular blockade to a TOFR of 0.9 . There were mild-tomoderate sugammadex-related adverse effects reported in all five studies, however, the benefits of reliably reversing neuromuscular blockade outweighed the risk of adverse outcomes. There were some limitations identified in this systematic review. There was variation among dosing methods in the studies included. Wu et al. (2014) utilized actual body weight to calculate reversal agent doses, Gaszynski et al. (2011) utilized corrected body weight, and the remaining studies did not clearly identify the weight used to determine doses. Three of the studies were financially supported by the pharmaceutical company Merck Sharp \& Dohme Corp, which owns and manufacturers sugammadex. The length of the surgical procedure, timing elapsed from the last dose of rocuronium, 
and concurrently administered anesthetic doses was not identified across studies, which could be considered a limitation. An additional limitation of this systematic review could be that only three databases were utilized to extract randomized control trials.

In summary, the five randomized control trials included in this systematic review supported sugammadex as reliable and consistent in producing a TOFR of 0.9 , in a significantly shorter time, when compared to neostigmine for reversal of rocuroniuminduced neuromuscular blockade.

Next, the recommendations and implications for advanced nursing practice will be discussed. 


\section{Recommendations and Implications for Advanced Nursing Practice}

Residual neuromuscular blockade is a serious and potentially life-threatening state that increases perioperative morbidity and mortality. Certified Registered Nurse Anesthetists (CRNAs), advanced practice nurses, have become integral members of the anesthesia care team. CRNAs administer more than 45 million anesthetics to patients each year in the United States (AANA, 2019). Anesthesia administration is both an art and science, in which emerging evidence and research must be continuously incorporated into practice in order to achieve clinical and professional competency.

There have been many proposed methods for assessment and evaluation of adequate neuromuscular recovery. The gold standard for adequate recovery from neuromuscular blockade is a TOFR of 0.9 by use of AMG. The ideal reversal agent would quickly and reliably achieve a TOFR of 0.9 without adverse effects. Traditionally, neuromuscular blockade has been reversed with an anticholinesterase, administered concurrently with an anticholinergic to reduce adverse effects. In recent years, selective relaxant-binding agents have been investigated to determine efficacy and reliability in reversing neuromuscular blockade.

Systematic reviews provide current information regarding the safest and most effective methods of administering anesthesia. The results of this systematic review demonstrate sugammadex can quickly and reliably reverse moderate levels of rocuronium-induced neuromuscular blockade without serious adverse consequences. All five studies showed faster recovery to a TOFR of 0.9 with sugammadex when compared to neostigmine. It is important to note that mortality was not increased in any cohorts studied. 
Further research on patient populations beyond the scope of this systematic review should be conducted to determine the safety profile of sugammadex in these groups. Furthermore, a cost analysis should be conducted to determine whether sugammadex has a comparable cost to neostigmine administered with an anticholinergic agent. An additional cost analysis should be conducted to determine whether reversal with sugammadex affects the amount of operating room (OR) time utilized, and therefore the cost of overall OR time, when compared to neostigmine.

CRNAs are uniquely positioned to provide safe patient care to a variety of patients in the perioperative period. Administration of sugammadex has been proven to be a faster and more reliable agent in preventing the incidence of adverse events related to residual neuromuscular blockade induced by rocuronium. Although sugammadex and neostigmine are both effective at reversing neuromuscular blockade, there are clinical situations where a faster and more reliable reversal using sugammadex would be preferred. For example, in a "cannot intubate and cannot ventilate" scenario immediately after induction of anesthesia, or when muscle relaxation is required to the end of a surgical procedure. Sugammadex may also be preferential in patients who cannot tolerate significant variations in heart rate, which may be observed when an anticholinesterase agent is utilized. These are examples of clinical situations in which the CRNA may want to advocate for use of sugammadex. CRNAs can become actively involved in developing appropriate treatment algorithms for use of sugammadex versus neostigmine + glycopyrrolate within the facilities they provide anesthesia based on current and emerging research. Additionally, CRNAs can educate colleagues on the clinical advantages of sugammadex. The CRNA, as an advanced practice nurse, has a 
duty to provide the most effective and appropriate care to patients, while mitigating adverse effects. Sugammadex has emerged as an appropriate and effective drug to mitigate adverse effects of neuromuscular blockade reversal, and the CRNA should be knowledgeable in the appropriate use of this medication. 


\section{References}

Alsaeed, A., Bamehriz, F., Eldin, S., Alzahrani, T., Alharbi, A., \& Eldawlatly, A. (2017). Sugammadex versus two doses of neostigmine for reversal of rocuronium in gastric sleeve surgery. Saudi Journal of Anesthesia, 11(3), 309-311.

American Association of Nurse Anesthetists (AANA). (2019). Certified registered nurse anesthetist fact sheet. Park Ridge, IL.

American Association of Nurse Anesthetists (AANA). (2013). Standards for nurse anesthesia practice. Park Ridge, IL.

Blobner, M., Eriksson, L.I., Scholz, J., Motsch, J., Rocca, G.D., \& Prins, M.E. (2010). Reversal of rocuronium-induced neuromuscular blockade with sugammadex compared with neostigmine during sevoflurane anaesthesia: Results of a randomized controlled trial. European Journal of Anaesthesiology, 27(10). doi: 10.1097/EJA.0b013e32833d56b7

Critical Appraisal Skills Programme. (2017). CASP systematic review checklist [data file]. Retrieved from http://media.wix.com/ugd/dded87_7e983a320087439e9 4533f4697aa109c.pdf

Gaszynski, T., Szewczyk, T., \& Gaszynski, W. (2011). Randomized comparison of sugammadex and neostigmine for reversal of rocuronium-induced muscle relaxation in morbidly obese undergoing general anaesthesia. British Journal of Anaesthesia, 108(2), 236-239. doi: 10.1093/bja/aer330

Geldner, G., Niskanen, M., Laurila, P., Mizikov, V., Hubler, M., Beck, G., ... Nicolayenko, E. (2012). A randomised controlled trial comparing sugammadex and neostigmine at different depths of neuromuscular blockade in patients 
undergoing laparoscopic surgery. Anaesthesia, 67, 991-998. doi: 10.1111/j.13652044.2012.07197.x

Illman, H.L., Laurila, P., Antila, H., Meretoja, O., Alahuhta, S., \& Olkkola, K. T. (2011). The duration of residual neuromuscular block after administration of neostigmine or sugammadex at two visible twitches during train-of-four monitoring. Anesthesia \& Analgesia, 112(1), 63-68. doi: 10.1213/ANE.0b013e3181fdf889

Jones, R., Caldwell, J., Brull, S., \& Soto, R. (2008). Reversal of profound rocuroniuminduced blockade with sugammadex. Anesthesiology, 109(5), 816-824.

Kirkland, M. (2013). The role of deep neuromuscular blockade in surgical procedures. Supplement to AANA Journal, 4-7.

Mathias, L., \& Bernardis, R. (2012). Postoperative residual paralysis. Brazilian Society of Anesthesiology, 62(3), 439-443.

Moher, D., Liberati, A., Tetzlaff, J., Altman, D., \& PRISMA Group. (2009). Preferred reporting items for systematic reviews and meta-analyses: The PRISMA statement. Annals of Internal Medicine, 151(4), 264-269. Retrieved from http://annals.org/

Nagelhout, J. (2013). Reversal of neuromuscular blocking agents: current practice. Supplement to AANA Journal, 8-11.

Nagelhout, J., \& Plaus, K. (2014). Nurse anesthesia ( $5^{\text {th }}$ ed.). St. Louis, MO: Elsevier. Naguib, M. (2015). Neuromuscular blocking drugs and reversal agents. In P. Flood, J. Rathmell, \& S. Shafer (5 ${ }^{\text {th }}$ ed.), Stoetling's pharmacology \& physiology in anesthetic practice (pp. 323-339). Philadelphia, PA: Wolters Kluwer Health.

Papathanas, M., \& Killian, A. (2017). Sugammadex for neuromuscular blockade reversal. 
Advanced Emergency Nursing Journal 39(4), 248-257.

Plummer-Roberts, A., Trost, C., Collins, S., \& Hewer, I. (2016). Residual neuromuscular blockade. AANA Journal, 84(1), 57-65.

Polit, D., \& Beck, C. (2017). Nursing research: Generating and assessing evidence for nursing practice. $\left(10^{\text {th }}\right.$ ed.). Philadelphia, PA: Wolters Kluwer: Lippincott Williams \& Wilkins.

Welliver, M. (2013). New and advanced options in neuromuscular blockade management. Supplement to AANA Journal, 12-20.

Wiatrowski, R., Martini, L., Flanagan, B., Freeman, K., \& Sloan, N. (2018). Residual neuromuscular blockade: Evidence-based recommendations to improve patient outcomes. AANA Journal, 86(2), 156-167.

Woo, T., Kim, K.S., Shim, Y.H., Kim, M.K., Yoon, S.M., Lim, Y,J., ... Chon, J.Y. (2013). Sugammadex versus neostigmine reversal of moderate rocuroniuminduced neuromuscular blockade in Korean patients. Korean Journal of Anesthesiology, 65(6), 501-507. https://dx.doi.org/10.4097/kjae.2013.65.6.501

Wu, X., Oerding, H., Liu, J., Vanacker, B., Yao, S., Dahl, V., ... Woo, T. (2014). Rocuronium blockade reversal with sugammadex vs. neostigmine: randomized study in chinese and caucasian subjects. BMC anesthesiology, 14(53). doi:10.1186/1471-2253-14-53 


\section{Appendix A}

\begin{tabular}{|c|c|c|c|}
\hline Monitoring Test & Definition & Comments & Stimulation Characteristics \\
\hline Single twitch & $\begin{array}{l}\text { A single supramaximal electrical } \\
\text { stimulus ranging from } 0.1-1.0 \mathrm{~Hz}\end{array}$ & $\begin{array}{l}\text { Requires baseline before drug administration; } \\
\text { generally used as a qualitative rather than } \\
\text { quantitative assessment }\end{array}$ & 1 \\
\hline Train-of-four & $\begin{array}{l}\text { A series of four twitches at } 2 \mathrm{~Hz} \\
\text { every } 1 / 2 \text { second for } 2 \mathrm{sec}\end{array}$ & $\begin{array}{l}\text { Reflects blockade from } 70 \%-100 \% \text {; useful } \\
\text { during onset, maintenance, and emergence } \\
\text { Train-of-four ratio is determined by comparing } \\
T_{1}-T_{4}\end{array}$ & $\underset{T_{1} T_{2}}{\mid}||_{T_{3} T_{4}}$ \\
\hline $\begin{array}{l}\text { Double-burst } \\
\text { simulation }\end{array}$ & $\begin{array}{l}\text { Two short bursts of } 50 \mathrm{~Hz} \text { tetanus } \\
\text { seperated by } 0.75 \mathrm{sec}\end{array}$ & $\begin{array}{l}\text { Similar to train-of-four; useful during onset, } \\
\text { maintenance, and emergence; may be } \\
\text { easier to detect fade than with train-of-four; } \\
\text { tactile evaluation }\end{array}$ & \\
\hline Tetanus & $\begin{array}{l}\text { Generally consists of rapid dellivery } \\
\text { of a } 30-, 50-\text {, or } 100-\mathrm{Hz} \text { stimulus } \\
\text { for } 5 \mathrm{sec}\end{array}$ & $\begin{array}{l}\text { Should be used sparingly for deep block } \\
\text { assessment; painful }\end{array}$ & |IIIIIIII| \\
\hline $\begin{array}{l}\text { Posttetanic } \\
\text { count }\end{array}$ & $\begin{array}{l}50-\mathrm{Hz} \text { tetanus for } 5 \mathrm{sec} \text {, a } 3-\mathrm{sec} \\
\text { pause, then single twitches } \\
\text { of } 1 \mathrm{~Hz}\end{array}$ & $\begin{array}{l}\text { Used only when train-of-four and double-burst } \\
\text { stimulation is absent; count of less than } \\
\text { eight indicates deep block, and prolonged } \\
\text { recovery is likely }\end{array}$ & \\
\hline
\end{tabular}

(Nagelhout \& Plaus, 2014) 


\section{Appendix B}

\section{PRISMA 2009 Checklist}

$+$

\begin{tabular}{|c|c|c|c|}
\hline Section/topic & $\#$ & Checklist item & $\begin{array}{l}\text { Reported } \\
\text { on page \# }\end{array}$ \\
\hline \multicolumn{4}{|l|}{ TITLE } \\
\hline Title & 1 & Identify the report as a systematic review, meta-analysis, or both. & \\
\hline \multicolumn{4}{|l|}{ ABSTRACT } \\
\hline Structured summary & 2 & $\begin{array}{l}\text { Provide a structured summary including, as applicable: background; objectives; data sources; study eligibility criteria, } \\
\text { participants, and interventions; study appraisal and synthesis methods; results; limitations; conclusions and } \\
\text { implications of key findings; systematic review registration number. }\end{array}$ & \\
\hline \multicolumn{4}{|l|}{ INTRODUCTION } \\
\hline Rationale & 3 & Describe the rationale for the review in the context of what is already known. & \\
\hline Objectives & 4 & $\begin{array}{l}\text { Provide an explicit statement of questions being addressed with reference to participants, interventions, comparisons, } \\
\text { outcomes, and study design (PICOS). }\end{array}$ & \\
\hline \multicolumn{4}{|l|}{ METHODS } \\
\hline Protocol and registration & 5 & $\begin{array}{l}\text { Indicate if a review protocol exists, if and where it can be accessed (e.g., Web address), and, if available, provide } \\
\text { registration information including registration number. }\end{array}$ & \\
\hline Eligibility criteria & 6 & $\begin{array}{l}\text { Specify study characteristics (e.g., PICOS, length of follow-up) and report characteristics (e.g., years considered, } \\
\text { language, publication status) used as criteria for eligibility, giving rationale. }\end{array}$ & \\
\hline Information sources & 7 & $\begin{array}{l}\text { Describe all information sources (e.g., databases with dates of coverage, contact with study authors to identify } \\
\text { additional studies) in the search and date last searched. }\end{array}$ & \\
\hline Search & 8 & $\begin{array}{l}\text { Present full electronic search strategy for at least one database, including any limits used, such that it could be } \\
\text { repeated. }\end{array}$ & \\
\hline Study selection & 9 & $\begin{array}{l}\text { State the process for selecting studies (i.e., screening, eligibility, included in systematic review, and, if applicable, } \\
\text { included in the meta-analysis). }\end{array}$ & \\
\hline Data collection process & 10 & $\begin{array}{l}\text { Describe method of data extraction from reports (e.g., piloted forms, independently, in duplicate) and any processes } \\
\text { for obtaining and confirming data from investigators. }\end{array}$ & \\
\hline Data items & 11 & $\begin{array}{l}\text { List and define all variables for which data were sought (e.g., PICOS, funding sources) and any assumptions and } \\
\text { simplifications made. }\end{array}$ & \\
\hline $\begin{array}{l}\text { Risk of bias in individual } \\
\text { studies }\end{array}$ & 12 & $\begin{array}{l}\text { Describe methods used for assessing risk of bias of individual studies (including specification of whether this was } \\
\text { done at the study or outcome level), and how this information is to be used in any data synthesis. }\end{array}$ & \\
\hline Summary measures & 13 & State the principal summary measures (e.g., risk ratio, difference in means). & \\
\hline Synthesis of results & 14 & $\begin{array}{l}\text { Describe the methods of handling data and combining results of studies, if done, including measures of consistency } \\
\left(\text { e.g., } 1^{2} \text { ) for each meta-analysis. }\right.\end{array}$ & \\
\hline
\end{tabular}

\begin{tabular}{|c|c|c|c|}
\hline Section/topic & $\#$ & Checklist item & $\begin{array}{l}\text { Reported } \\
\text { on page \# }\end{array}$ \\
\hline Risk of bias across studies & 15 & $\begin{array}{l}\text { Specify any assessment of risk of bias that may affect the cumulative evidence (e.g., publication bias, selective } \\
\text { reporting within studies). }\end{array}$ & \\
\hline Additional analyses & 16 & $\begin{array}{l}\text { Describe methods of additional analyses (e.g., sensitivity or subgroup analyses, meta-regression), if done, indicating } \\
\text { which were pre-specified. }\end{array}$ & \\
\hline \multicolumn{4}{|l|}{ RESULTS } \\
\hline Study selection & 17 & $\begin{array}{l}\text { Give numbers of studies screened, assessed for eligibility, and included in the review, with reasons for exclusions at } \\
\text { each stage, ideally with a flow diagram. }\end{array}$ & \\
\hline Study characteristics & 18 & $\begin{array}{l}\text { For each study, present characteristics for which data were extracted (e.g., study size, PICOS, follow-up period) and } \\
\text { provide the citations. }\end{array}$ & \\
\hline Risk of bias within studies & 19 & Present data on risk of bias of each study and, if available, any outcome level assessment (see item 12). & \\
\hline Results of individual studies & 20 & $\begin{array}{l}\text { For all outcomes considered (benefits or harms), present, for each study: (a) simple summary data for each } \\
\text { intervention group (b) effect estimates and confidence intervals, ideally with a forest plot. }\end{array}$ & \\
\hline Synthesis of results & 21 & Present results of each meta-analysis done, including confidence intervals and measures of consistency. & \\
\hline Risk of bias across studies & 22 & Present results of any assessment of risk of bias across studies (see Item 15). & \\
\hline Additional analysis & 23 & Give results of additional analyses, if done (e.g., sensitivity or subgroup analyses, meta-regression [see Item 16]). & \\
\hline \multicolumn{4}{|l|}{ DISCUSSION } \\
\hline Summary of evidence & 24 & $\begin{array}{l}\text { Summarize the main findings including the strength of evidence for each main outcome; consider their relevance to } \\
\text { key groups (e.g., healthcare providers, users, and policy makers). }\end{array}$ & \\
\hline Limitations & 25 & $\begin{array}{l}\text { Discuss limitations at study and outcome level (e.g., risk of bias), and at review-level (e.g., incomplete retrieval of } \\
\text { identified research, reporting bias). }\end{array}$ & \\
\hline Conclusions & 26 & Provide a general interpretation of the results in the context of other evidence, and implications for future research. & \\
\hline \multicolumn{4}{|l|}{ FUNDING } \\
\hline Funding & 27 & $\begin{array}{l}\text { Describe sources of funding for the systematic review and other support (e.g., supply of data); role of funders for the } \\
\text { systematic review. }\end{array}$ & \\
\hline
\end{tabular}

(Moher et al., 2009) 


\section{Appendix C}

\section{PRISMA 2009 Flow Diagram}

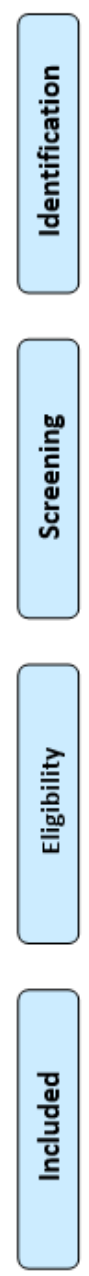

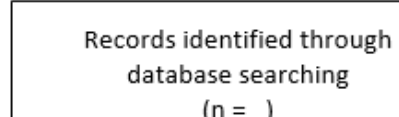

( $\mathrm{n}=1$
Additional records identified through other sources $(\mathrm{n}=)$

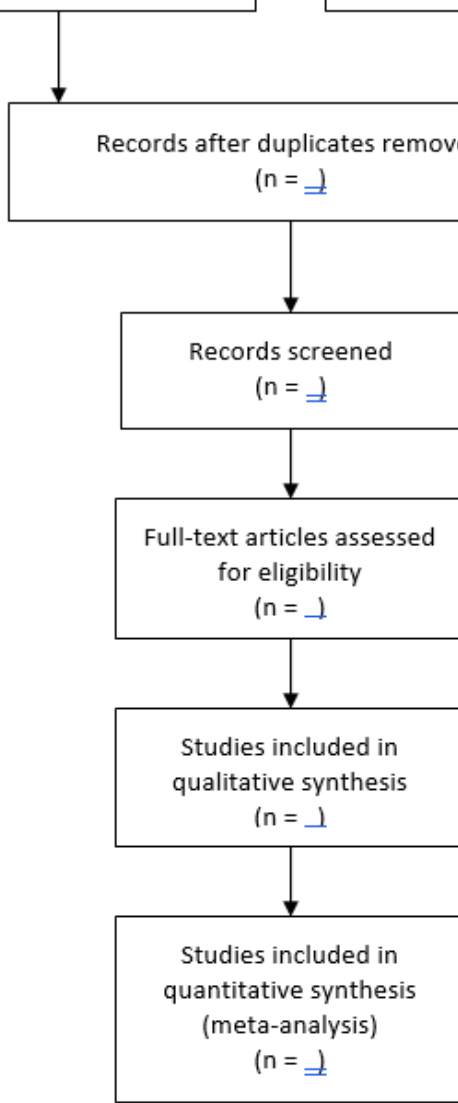

(Moher et al., 2009) 


\section{Appendix D}

\section{Data Extraction Tables}

Table D1 - Wu, X., Oerding, H., Liu, J., Vanacker, B., Yao, S., Dahl, V., ... Woo, T. (2014). Rocuronium blockade reversal with sugammadex vs. neostigmine: randomized study in Chinese and Caucasian subjects. BMC anesthesiology, 14(53). doi:10.1186/1471$2253-14-53$

\begin{tabular}{|c|c|c|c|}
\hline Site/Sample & Method/Design & $\begin{array}{c}\text { Time to TOFR of } 0.9 \\
\text { with Sugammadex }\end{array}$ & $\begin{array}{l}\text { Time to TOFR of } 0.9 \\
\text { with Neostigmine }\end{array}$ \\
\hline $\begin{array}{l}\text { Multi-center study (6 } \\
\text { sites in China \& } 4 \text { sites } \\
\text { in Europe) }\end{array}$ & $\begin{array}{l}\text { Randomized, parallel group, multicenter, safety- } \\
\text { assessor blinded study }\end{array}$ & $\begin{array}{l}1.6 \text { minutes in Chinese } \\
\text { subjects }\end{array}$ & $\begin{array}{l}9.1 \text { minutes in Chinese } \\
\text { subjects }\end{array}$ \\
\hline $\begin{array}{l}289 \text { Subjects enrolled } \\
\text { in trial (230 Chinese } \\
\text { subjects \& } 59 \\
\text { Caucasian subjects) }\end{array}$ & $\begin{array}{l}\text { Screening of subjects took place } \leq 7 \text { days prior to } \\
\text { treatment administration. Eligible subjects were } \\
\text { randomized via a computerized central } \\
\text { randomization system in a } 1: 1 \text { ratio to either } \\
\text { receive: sugammadex } 2 \mathrm{mg} / \mathrm{kg} \text { or neostigmine } \\
50 \mathrm{mcg} / \mathrm{kg} \text { with atropine } 10-20 \mathrm{mcg} / \mathrm{kg}\end{array}$ & $\begin{array}{c}1.4 \text { minutes in } \\
\text { Caucasian subjects }\end{array}$ & $\begin{array}{c}6.7 \text { minutes in } \\
\text { Caucasian subjects }\end{array}$ \\
\hline $\begin{array}{l}\text { Subjects aged 18-64 } \\
\qquad \text { years } \\
\text { Undergoing Elective } \\
\text { Surgery } \\
\text { ASA Class } \leq 3\end{array}$ & $\begin{array}{l}\text { Anesthesia induced and maintained with IV } \\
\text { propofol, opioids administered according to local } \\
\text { practice. Rocuronium } 0.6 \mathrm{mg} / \mathrm{kg} \text { was administered } \\
\text { prior to intubation. Rocuronium maintenance doses } \\
\text { of } 0.1-0.2 \mathrm{mg} / \mathrm{kg} \text { were administered as required for } \\
\text { the anesthetic. After the last dose of rocuronium, at } \\
\text { the reappearance of a second twitch }\left(\mathrm{T}_{2}\right) \text {, the } \\
\text { reversal agents were administered. }\end{array}$ & & \\
\hline
\end{tabular}




\begin{tabular}{|c|c|c|c|}
\hline $\begin{array}{c}\text { Type of } \\
\text { Elective } \\
\text { Procedure }\end{array}$ & Adverse Events & Results & Limitations \\
\hline Not specified & $\begin{array}{c}11 \text { subjects experienced } \\
\text { bradycardia after study drugs: } 7 \\
\text { Chinese subjects ( } 1 \text { received } \\
\text { sugammadex; } 6 \text { received } \\
\text { neostigmine) \& } 4 \text { Caucasian } \\
\text { subjects (all } 4 \text { received } \\
\text { neostigmine) } \\
10 \text { Chinese subjects } \\
\text { experienced hypersensitivity } \\
\text { reactions characterized by: } \\
\text { mild-to-moderate rash, pruritis, } \\
\text { facial swelling, \& facial } \\
\text { flushing: } 7 \text { Chinese subjects } \\
\text { received sugammadex; } 3 \\
\text { Chinese subjects received } \\
\text { neostigmine }\end{array}$ & $\begin{array}{l}\text { Sugammadex provided more rapid } \\
\text { reversal of rocuronium-induced } \\
\text { neuromuscular blockade compared } \\
\text { with neostigmine in both Chinese } \& \\
\text { Caucasian subjects } \\
\text { Chinese subjects experienced a } \\
\text { recovery time that was } 5.7 \text { times } \\
\text { faster with sugammadex versus } \\
\text { neostigmine ( } p<0.0001) \\
\text { Caucasian subjects experienced } \\
\text { recovery from rocuronium-induced } \\
\text { neuromuscular blockade } 4.8 \text { times } \\
\text { faster with sugammadex versus } \\
\text { neostigmine }(p<0.0001)\end{array}$ & $\begin{array}{l}\text { Doses of neuromuscular blocking } \\
\text { agents were based on actual body } \\
\text { weight instead of ideal body weight } \\
\text { Length of surgical procedure not } \\
\text { specified } \\
\text { Financial support provided by } \\
\text { Merck Sharp \& Dohme Corp. } \\
\text { Time elapsed from last dose of } \\
\text { rocuronium not specified } \\
\text { Type of surgical procedure not } \\
\text { specified }\end{array}$ \\
\hline
\end{tabular}


Table D2 - Woo, T., Kim, K.S., Shim, Y.H., Kim, M.K., Yoon, S.M., Lim, Y,J., ... Chon, J.Y. (2013). Sugammadex versus neostigmine reversal of moderate rocuronium-induced neuromuscular blockade in Korean patients. Korean Journal of

Anesthesiology, 65(6), 501-507. https://dx.doi.org/10.4097/kjae.2013.65.6.501

\begin{tabular}{|c|c|c|c|}
\hline Site/Sample & Method/Design & $\begin{array}{c}\text { Time to TOFR of } \\
0.9 \text { with } \\
\text { Sugammadex }\end{array}$ & $\begin{array}{c}\text { Time to TOFR of } 0.9 \\
\text { with Neostigmine }\end{array}$ \\
\hline $\begin{array}{c}\text { Multi-center } \\
\text { study (7 sites in } \\
\text { the Republic of } \\
\text { Korea) } \\
\text { Subjects were of } \\
\text { Korean descent - } \\
\text { born in Korea, } \\
\text { never emigrated } \\
\text { from Korea, with } \\
\text { a Korean home } \\
\text { address (n=118) } \\
\text { Subjects } \\
\text { undergoing } \\
\text { elective surgical } \\
\text { procedure } \\
\text { ASA Class } \leq 3\end{array}$ & $\begin{array}{l}\text { Randomized, parallel-group, active-controlled, safety } \\
\text { assessor-blinded phase IV study } \\
\text { Subjects were randomized on } 1: 1 \text { basis to receive either: } \\
\text { sugammadex } 2 \mathrm{mg} / \mathrm{kg} \text { or neostigmine } 50 \mathrm{mcg} / \mathrm{kg} \text { plus } \\
\text { glycopyrrolate } 10 \mathrm{mcg} / \mathrm{kg} \text { for NMB reversal } \\
\text { Anesthesia induced with IV propofol \& maintained with } \\
\text { sevoflurane. Opioids were administered per local practice. } \\
\text { Rocuronium } 0.6 \mathrm{mg} / \mathrm{kg} \text { was administered for intubation and } \\
\text { was re-dosed as clinically indicated in } 0.1-0.2 \mathrm{mg} / \mathrm{kg} \text { doses. } \\
\text { After the final dose of rocuronium, at the reappearance of a } \\
\text { T2, the reversal agents were administered. } \\
\text { The anesthesia provider administering the anesthesia during } \\
\text { the surgery was not blinded to the randomized study drug, } \\
\text { but was not allowed to reveal the assigned treatment group } \\
\text { to the safety assessor } \\
\text { Blinded safety assessor performed safety assessments in the } \\
\text { postoperative period }\end{array}$ & $\begin{array}{c}1.8 \text { minutes } \\
\text { following } \\
\text { administration of } \\
\text { sugammadex } \\
2 \mathrm{mg} / \mathrm{kg}\end{array}$ & $\begin{array}{c}14.8 \text { minutes } \\
\text { following } \\
\text { administration of } \\
\text { neostigmine } \\
50 \mathrm{mcg} / \mathrm{kg}\end{array}$ \\
\hline
\end{tabular}




\begin{tabular}{|c|c|c|c|}
\hline Type of Elective Procedure & Adverse Events & Results & Limitations \\
\hline $\begin{array}{l}\text { Operations of the ear, nose, } \\
\quad \& \text { larynx }(48 \%) \\
\text { Operations of female genital } \\
\text { organs (18\%) } \\
\text { Operations of digestive } \\
\text { system \& spleen }(17 \%)\end{array}$ & $\begin{array}{l}\text { Treatment related adverse } \\
\quad \begin{array}{l}\text { events: } \\
\text { - }\end{array} \\
\begin{array}{l}\text { sugamects in } \\
\text { (bradycadex group } \mathrm{n}=1 ;\end{array} \\
\text { headache, } \mathrm{n}=3 \text { ) } \\
\text { - } 6 \text { subjects in } \\
\text { neostigmine group } \\
\text { (headache, } \mathrm{n}=2 ; \\
\text { nausea, } \mathrm{n}=1 ; \text { recurrence } \\
\text { NMB, } \mathrm{n}=1 ; \text { rash, } \mathrm{n}=1 ; \\
\text { hypotension, } \mathrm{n}=1 \text { ) }\end{array}$ & $\begin{array}{l}\text { Recovery from rocuronium- } \\
\text { induced neuromuscular } \\
\text { blockade was } 8.1 \text { times faster } \\
\text { with sugammadex versus } \\
\text { neostigmine in Korean subjects } \\
\quad(\mathrm{P}<0.0001)\end{array}$ & $\begin{array}{l}\text { Doses of study related drugs } \\
\text { was not specific regarding } \\
\text { whether ideal body weight or } \\
\text { actual body weight was used } \\
\text { to determine dosing } \\
\text { Time elapsed from last dose } \\
\text { of rocuronium not specified } \\
\text { Length of surgical procedure } \\
\text { not specified } \\
\text { Financial support provided } \\
\text { by Merck Sharp \& Dohme } \\
\text { Corp. }\end{array}$ \\
\hline
\end{tabular}


Table D3 - Gaszynski, T., Szewczyk, T., \& Gaszynski, W. (2011). Randomized comparison of sugammadex and neostigmine for reversal of rocuronium-induced muscle relaxation in morbidly obese undergoing general anaesthesia. British Journal of Anaesthesia,

108(2), 236-239. doi: 10.1093/bja/aer330

\begin{tabular}{|c|c|c|c|}
\hline Site/Sample & Method/Design & $\begin{array}{l}\text { Time to TOFR } \\
\text { of } 0.9 \text { with } \\
\text { Sugammadex }\end{array}$ & $\begin{array}{c}\text { Time to TOFR } \\
\text { of } 0.9 \text { with } \\
\text { Neostigmine }\end{array}$ \\
\hline $\begin{array}{l}\text { Single center } \\
\text { study performed } \\
\text { at the Medical } \\
\text { University of } \\
\text { Lodz, Poland } \\
70 \text { morbidly } \\
\text { obese subjects } \\
\text { (BMI > 40) } \\
\text { requiring general } \\
\text { anesthesia \& } \\
\text { muscle relaxation } \\
\text { with rocuronium } \\
\text { Undergoing } \\
\text { elective bariatric } \\
\text { surgery }\end{array}$ & $\begin{array}{l}\text { Prospective, randomized, safety-assessor blinded study } \\
\text { Subjects were randomized to receive either: sugammadex } 2 \mathrm{mg} / \mathrm{kg} \text { of } \\
\text { corrected body weight (CBW) or neostigmine } 0.05 \mathrm{mg} / \mathrm{kg} \mathrm{CBW} \text { with } \\
\text { atropine } 0.02 \mathrm{mg} / \mathrm{kg} \mathrm{CBW} \text {. Envelopes previously prepared by the } \\
\text { investigator were used for randomization. } \\
\text { Both groups had anesthesia induced with propofol } 1.5-2 \mathrm{mg} / \mathrm{kg} \mathrm{CBW} \text {. } \\
\text { Fentanyl } 0.05 \mathrm{mg} / \mathrm{kg} \mathrm{CBW} \text { administered for analgesia. Anesthesia was } \\
\text { maintained with an air, oxygen, \& desflurane mixture. Volume \% of } \\
\text { desflurane was based on age, clinical status, \& monitoring. Neuromuscular } \\
\text { blockade was induced using rocuronium } 1 \mathrm{mg} / \mathrm{kg} \mathrm{CBW} \text {. A maximum of } \\
\text { two additional doses of rocuronium } 0.06 \mathrm{mg} / \mathrm{kg} \text { CBW were given when a } \\
\text { TOFR reached } 1 \text {. } \\
\text { At surgery completion and reappearance of T }{ }_{2} \text { twitch, reversal agents were } \\
\text { administered, and time recorded. } \\
\text { A blinded investigator continued to monitor TOF stimulation \& perform } \\
\text { safety assessments in the postoperative period }\end{array}$ & $\begin{array}{l}2 \text { minutes } 44 \\
\text { seconds } \\
\text { following } \\
\text { administration } \\
\text { of sugammadex } \\
2 \mathrm{mg} / \mathrm{kg} \mathrm{CBW}\end{array}$ & $\begin{array}{c}9 \text { minutes } 37 \\
\text { seconds } \\
\text { following } \\
\text { administration of } \\
\text { neostigmine } \\
0.05 \mathrm{mg} / \mathrm{kg} \mathrm{CBW}\end{array}$ \\
\hline
\end{tabular}




\begin{tabular}{|c|c|c|c|}
\hline $\begin{array}{l}\text { Type of Elective } \\
\text { Procedure }\end{array}$ & Adverse Events & Results & Limitations \\
\hline $\begin{array}{l}\text { Elective bariatric } \\
\text { surgery }\end{array}$ & $\begin{array}{l}\text { Treatment related } \\
\text { adverse events } \\
\text { included: } \\
2 \text { subjects in } \\
\text { sugammadex group } \\
\text { reported "a strange taste } \\
\text { in the mouth" } \\
3 \text { subjects in the } \\
\text { negostigmine group had } \\
\text { significant bradycardia } \\
\text { that required additional } \\
\text { administration of } \\
\text { atropine }\end{array}$ & $\begin{array}{l}\text { Total dose of } \\
\text { rocuronium was } \\
\text { comparable between } \\
\text { the two groups } \\
\text { (sugammadex } \\
\text { group: } 87.9 \mathrm{mg} \text {; } \\
\text { neostigmine group: } \\
85.6 \mathrm{mg} \text { ). } \\
\text { Mean time to } \\
\text { achieve TOFR } 0.9 \\
\text { was } 3.5 \text { times } \\
\text { shorter in the } \\
\text { subjects who } \\
\text { received } \\
\text { sugammadex } \\
(\mathrm{P}<0.05)\end{array}$ & $\begin{array}{l}\text { Investigator previously prepared envelopes for randomization, } \\
\text { which may increase risk for selection bias } \\
\text { Small sample size } \\
\text { ASA classification \& age of participants omitted from reported } \\
\text { data } \\
\text { Use of CBW may have resulted in under-dosing in the obese } \\
\text { patient. Use of CBW was utilized based on recommendations } \\
\text { from prior authors. Manufacturer recommends dosing on actual } \\
\text { body weight. } \\
\text { Standard anesthesia practice in Poland utilizes paired use of } \\
\text { atropine \& neostigmine; glycopyrrolate may be better paired with } \\
\text { neostigmine \& may have altered the prevalence of adverse events } \\
\text { reported } \\
\text { Percent of inspired volatile agent not reported, higher doses may } \\
\text { potentiate neuromuscular blockade } \\
\text { Length of surgical procedure not specified }\end{array}$ \\
\hline
\end{tabular}


Table D4 - Illman, H.L., Laurila, P., Antila, H., Meretoja, O., Alahuhta, S., \& Olkkola, K. T. (2011). The duration of residual

neuromuscular block after administration of neostigmine or sugammadex at two visible twitches during train-of-four monitoring.

Anesthesia \& Analgesia, 112(1), 63-68. doi: 10.1213/ANE.0b013e3181fdf889

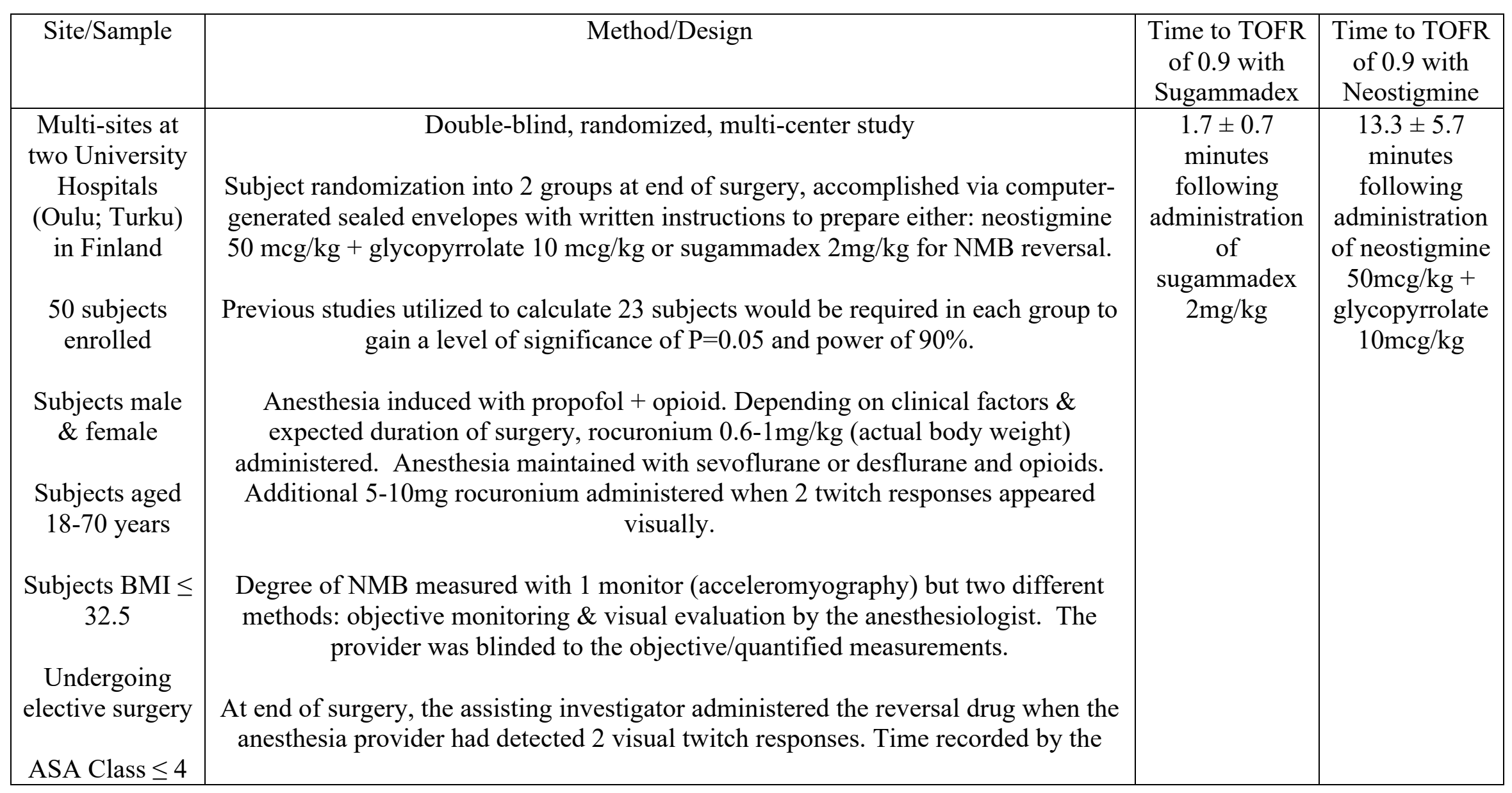




\begin{tabular}{|c|c|c|c|}
\hline & \multicolumn{2}{|c|}{$\begin{array}{l}\text { anesthesia provider when } 3 \text { and } 4 \text { twitches and no visual fade was detected after } \\
\text { administration of reversal. Provider remained blinded to reversal drug administered. }\end{array}$} & \\
\hline $\begin{array}{c}\text { Type of } \\
\text { Elective } \\
\text { Procedure }\end{array}$ & Adverse Events & Results & Limitations \\
\hline
\end{tabular}


Table D5 - Blobner, M., Eriksson, L.I., Scholz, J., Motsch, J., Rocca, G.D., \& Prins, M.E. (2010). Reversal of rocuronium-induced

neuromuscular blockade with sugammadex compared with neostigmine during sevoflurane anaesthesia: Results of a randomized

controlled trial. European Journal of Anaesthesiology, 27(10). doi: 10.1097/EJA.0b013e32833d56b7

\begin{tabular}{|c|c|c|c|}
\hline Site/Sample & Method/Design & $\begin{array}{c}\text { Time to TOFR } \\
\text { of } 0.9 \text { with } \\
\text { Sugammadex }\end{array}$ & $\begin{array}{c}\text { Time to TOFR of } \\
0.9 \text { with } \\
\text { Neostigmine }\end{array}$ \\
\hline $\begin{array}{c}\text { Age } \geq 18 \\
\text { years } \\
\text { No } \\
\text { restrictions } \\
\text { on subject } \\
\text { body weight } \\
\text { Male \& } \\
\text { female } \\
\text { subjects } \\
\text { included } \\
\text { Undergoing } \\
\text { elective } \\
\text { surgery under } \\
\text { general } \\
\text { anesthesia }\end{array}$ & $\begin{array}{l}\text { Multi-center, randomized, parallel-group, comparative, active-controlled, } \\
\text { safety-assessor-blinded trial. Researched determined to have a power of } 95 \% \\
\text { to detect a difference, a minimum of } 46 \text { subjects needed to be enrolled in } \\
\text { each group. N=49 for each group was utilized in case subjects dropped out of } \\
\text { the study. Patients were randomized to receive rocuronium or vecuronium; } \\
\text { only the results of the subjects who received rocuronium are published in this } \\
\text { study. Subjects who received rocuronium were randomized to receive either: } \\
\text { sugammadex } 2 \mathrm{mg} / \mathrm{kg} \text { or neostigmine } 50 \mathrm{mcg} / \mathrm{kg}+\text { glycopyrrolate } 10 \mathrm{mcg} / \mathrm{kg} \text {. } \\
\text { Anesthesia induced with propofol and maintained with sevoflurane }+ \text { opioid } \\
\text { supplementation as clinically indicated. After baseline acceleromyography } \\
\text { recording, rocuronium } 0.6 \mathrm{mg} / \mathrm{kg} \text { administered for intubation. Maintenance } \\
\text { doses of } 0.1-0.2 \mathrm{mg} / \mathrm{kg} \text { administered based on clinical need. } \\
\text { When NMB was no longer required, subjects were allowed to recover to a } \\
\text { reappearance of T } 2 \text { twitch, then reversal agents were administered IV. } \\
\text { Sevoflurane concentrations were maintained for a period of } 10 \text { minutes } \\
\text { following reversal agent administration or decreased when a TOFR } 0.9 \text { was } \\
\text { achieved. Any patient who did not return to a TOFR of } 0.9 \text { within } 10 \text { minutes } \\
\text { of reversal agent administration remained sedated, intubated, \& ventilated in } \\
\text { the recovery room until a TOFR } 0.9 \text { was achieved for safe extubation. }\end{array}$ & $\begin{array}{c}1.5 \text { minutes to } \\
\text { recover to a } \\
\text { TOFR } 0.9 \\
\text { following } \\
\text { administration of } \\
\text { sugammadex } \\
2 \mathrm{mg} / \mathrm{kg}\end{array}$ & $\begin{array}{c}18.6 \text { minutes to } \\
\text { recover to a TOFR } \\
0.9 \text { following } \\
\text { administration of } \\
\text { neostigmine } \\
50 \mathrm{mcg} / \mathrm{kg}+ \\
\text { glycopyrrolate } \\
10 \mathrm{mcg} / \mathrm{kg}\end{array}$ \\
\hline
\end{tabular}


\begin{tabular}{|l|l|l}
\hline ASA Class $\leq$ & Postoperative clinical assessments were performed by the blinded safety
\end{tabular} 3 assessor.

\begin{tabular}{|c|c|c|c|}
\hline Type of Elective Procedure & Adverse Events & Results & Limitations \\
\hline $\begin{array}{l}\text { Distribution of surgical procedures: } \\
\text { Operations of ear, nose, \& larynx (19\%) } \\
\text { Operations of teeth, jaws, mouth, \& } \\
\text { pharynx (16\%) } \\
\text { Operations of digestive system \& spleen } \\
\text { (16\%) } \\
\text { Operations of urinary system, male genital } \\
\text { organs, \& retroperitoneal space (13\%) } \\
\text { Operations of musculoskeletal system } \\
(12 \%) \\
\text { Operations of female genital organs }(9 \%) \\
\text { Operations of endocrine system (7\%) } \\
\text { Operations of eye \& adjacent structure } \\
(4 \%)\end{array}$ & 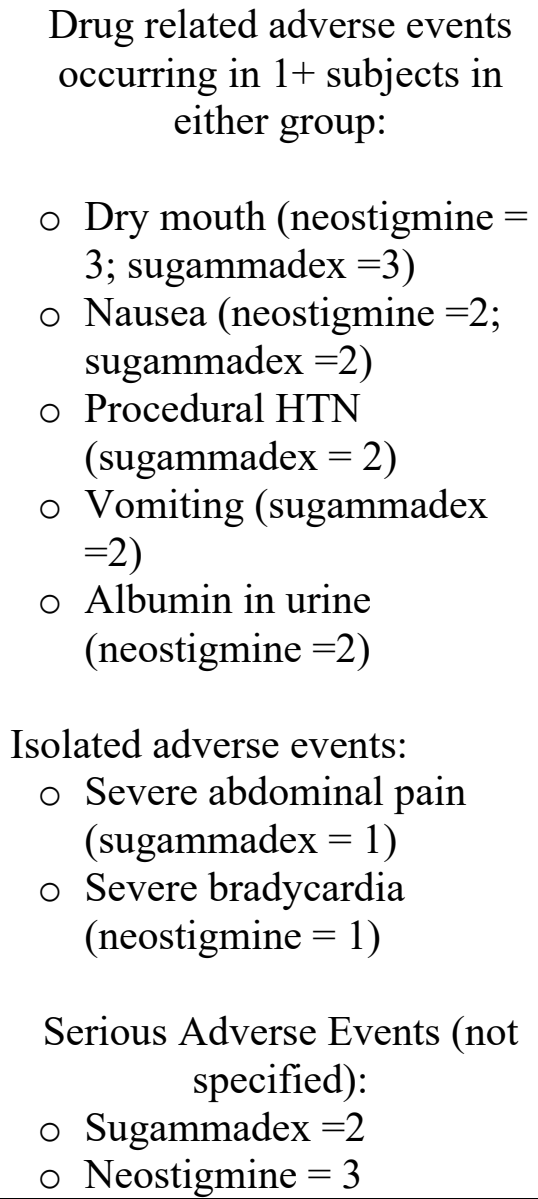 & $\begin{array}{l}\text { Treatment groups were } \\
\text { comparable regarding: age, } \\
\text { weight, \& height } \\
\text { Distribution of surgical } \\
\text { procedures was comparable } \\
\text { across treatment groups } \\
\text { Maintenance doses of inspired } \\
\text { sevoflurance and total doses of } \\
\text { rocuronium were comparable } \\
\text { between groups } \\
\text { All study sites had consistent } \\
\text { results when comparing } \\
\text { sugammadex vs. neostigmine } \\
\text { Sugammadex was faster in } \\
\text { attaining a TOFR } 0.9 \text { than } \\
\text { neostigmine when rocuronium- } \\
\text { induced NMB was present } \\
(P<0.0001)\end{array}$ & $\begin{array}{c}\text { Financial support } \\
\text { provided by Merck } \\
\text { Sharp \& Dohme } \\
\text { Corp. } \\
\text { Doses of study } \\
\text { related drugs was } \\
\text { not specific } \\
\text { regarding whether } \\
\text { ideal body weight } \\
\text { or actual body } \\
\text { weight was used to } \\
\text { determine dosing }\end{array}$ \\
\hline
\end{tabular}




\section{Appendix E}

Critical Appraisal Skills Programme (CASP) Tables

\begin{tabular}{|c|c|c|c|c|}
\hline & 11 Questions & Yes & $\begin{array}{c}\text { Can't } \\
\text { Tell }\end{array}$ & No \\
\hline 1 & Did the trial address a clearly focused issue? & & & \\
\hline 2 & $\begin{array}{l}\text { Was the assignment of patients to treatments } \\
\text { randomized? }\end{array}$ & & & \\
\hline 3 & $\begin{array}{l}\text { Were all the patients who entered the trial properly } \\
\text { accounted for at its conclusion? }\end{array}$ & & & \\
\hline 4 & $\begin{array}{l}\text { Were patients, health workers, and study personnel } \\
\text { 'blind' to treatment? }\end{array}$ & & & \\
\hline 5 & Were the groups similar at the start of the trial? & & & \\
\hline 6 & $\begin{array}{l}\text { Aside from the experimental interventions, were the } \\
\text { groups treated equally? }\end{array}$ & & & \\
\hline 7 & How large was the treatment effect? & & & \\
\hline 8 & How precise was the estimate of the treatment effect? & & & \\
\hline 9 & $\begin{array}{l}\text { Can the results be applied in your context? (Or to the } \\
\text { local population?) }\end{array}$ & & & \\
\hline 10 & Were all clinically important outcomes considered? & & & \\
\hline 11 & Are the benefits worth the harms and costs? & & & \\
\hline
\end{tabular}

(CASP, 2017) 
Table E1 - Wu, X., Oerding, H., Liu, J., Vanacker, B., Yao, S., Dahl, V., ... Woo, T.

(2014). Rocuronium blockade reversal with sugammadex vs. neostigmine: randomized study in Chinese and Caucasian subjects. BMC anesthesiology, 14(53).

doi:10.1186/1471-2253-14-53

\begin{tabular}{|c|c|c|c|c|}
\hline & 11 Questions & Yes & $\begin{array}{c}\text { Can't } \\
\text { Tell }\end{array}$ & No \\
\hline 1 & $\begin{array}{l}\text { Did the trial address a clearly focused issue? Yes, the } \\
\text { primary objective of this study was to evaluate the efficacy and } \\
\text { safety of sugammadex versus neostigmine to reverse } \\
\text { rocuronium-induced neuromuscular blockade in Chinese } \\
\text { subjects }(n=230) \text {. Caucasian subjects were included with a } \\
\text { smaller sample size }(n=59) \text { since efficacy had been previously } \\
\text { established in Caucasian subjects in previous studies. A } \\
\text { sample of ASA I, II, III adults undergoing elective surgery with } \\
\text { general anesthesia were recruited. }\end{array}$ & $\checkmark$ & & \\
\hline 2 & $\begin{array}{l}\text { Was the assignment of patients to treatments randomized? } \\
\text { Yes, subjects were randomized via a central, computer- } \\
\text { generated randomization schedule. Subjects were randomized } \\
\text { in a } 1: 1 \text { ratio to received either sugammadex } 2 \mathrm{mg} / \mathrm{kg} \text { or } \\
\text { neostigmine } 50 \mathrm{mcg} / \mathrm{kg} \text { with atropine } 10-20 \mathrm{mcg} / \mathrm{kg} \text {. }\end{array}$ & $\checkmark$ & & \\
\hline 3 & $\begin{array}{l}\text { Were all the patients who entered the trial properly } \\
\text { accounted for at its conclusion? Yes, } 308 \text { subjects were } \\
\text { included for randomization of treatment. } 17 \text { discontinued prior } \\
\text { to treatment. Of the } 291 \text { subjects who received treatment, } 2 \\
\text { were excluded from data analysis. }\end{array}$ & $\checkmark$ & & \\
\hline 4 & $\begin{array}{l}\text { Were patients, health workers, and study personnel 'blind' } \\
\text { to treatment? Patients who consented to study participation, } \\
\text { were blinded to whether they received sugammadex or } \\
\text { neostigmine + atropine. Anesthesia providers administering } \\
\text { the medications were not blinded to the treatment in which } \\
\text { their patient received. Study personnel in the postoperative } \\
\text { period were blinded to treatment. }\end{array}$ & & & $\checkmark$ \\
\hline 5 & $\begin{array}{l}\text { Were the groups similar at the start of the trial? The } \\
\text { groups were racially divided at the start of the study, as the } \\
\text { purpose of this trial was to determine efficacy in Chinese } \\
\text { subjects. (Since efficacy had already been established in } \\
\text { Caucasian subjects in previous studies.) Characteristics that } \\
\text { were similar across groups included: elective surgical } \\
\text { procedure, ASA class I, II, III, and rocuronium-induced }\end{array}$ & & & $\checkmark$ \\
\hline
\end{tabular}




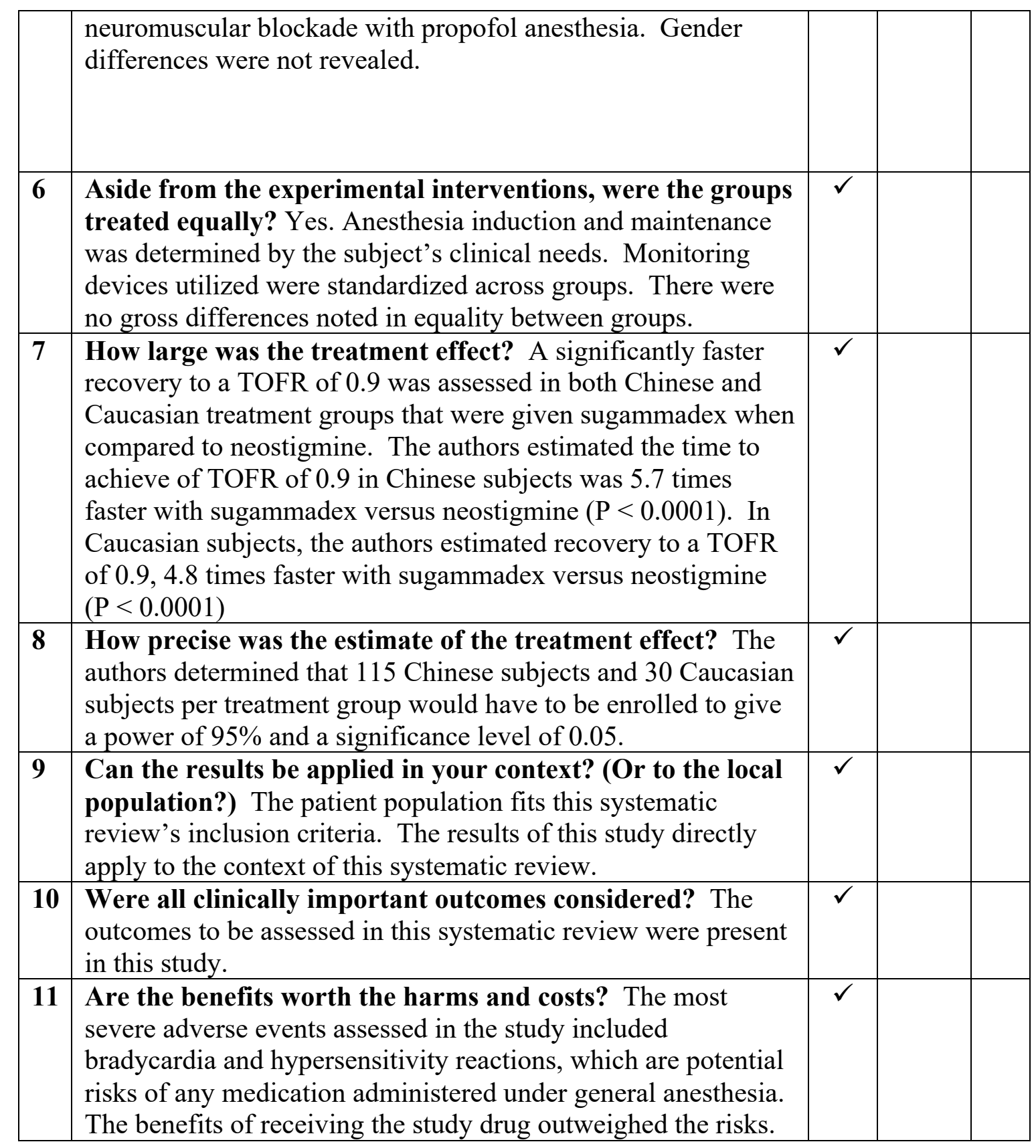


Table E2 - Woo, T., Kim, K.S., Shim, Y.H., Kim, M.K., Yoon, S.M., Lim, Y,J., ... Chon,

J.Y. (2013). Sugammadex versus neostigmine reversal of moderate rocuronium-induced

neuromuscular blockade in Korean patients. Korean Journal of Anesthesiology, 65(6),

501-507. https://dx.doi.org/10.4097/kjae.2013.65.6.501

\begin{tabular}{|c|c|c|c|c|}
\hline & 11 Questions & Yes & $\begin{array}{c}\text { Can't } \\
\text { Tell }\end{array}$ & No \\
\hline 1 & $\begin{array}{l}\text { Did the trial address a clearly focused issue? The purpose } \\
\text { of this study was to establish the safety and efficacy of } \\
\text { sugammadex versus neostigmine as the reversal agent for } \\
\text { rocuronium-induced neuromuscular blockade in Korean } \\
\text { patients. A sample of patients ASA class I, II, III, undergoing } \\
\text { an elective surgical procedure under general anesthesia using } \\
\text { rocuronium for induction and maintenance of neuromuscular } \\
\text { blockade were included. Subjects were of Korean descent, } \\
\text { born in Korea, with a current Korean home address, and never } \\
\text { having emigrated out of Korea. }\end{array}$ & $\checkmark$ & & \\
\hline 2 & $\begin{array}{l}\text { Was the assignment of patients to treatments } \\
\text { randomized? Patient were randomized into } 2 \text { groups on a } \\
1: 1 \text { basis, however the study personnel did not provide } \\
\text { specific information on how the randomization process was } \\
\text { completed. }\end{array}$ & $\checkmark$ & & \\
\hline 3 & $\begin{array}{l}\text { Were all the patients who entered the trial properly } \\
\text { accounted for at its conclusion? A total of } 128 \text { patients } \\
\text { were randomized into the study. A patient disposition chart } \\
\text { was included to diagram the flow of subjects throughout the } \\
\text { study. } 64 \text { patients were allocated into each study group. } 4 \\
\text { subjects from each group did not receive the intervention for } \\
\text { "administrative reasons". } 1 \text { subject from each group was } \\
\text { excluded from analysis due to lacking efficacy data. Of the } \\
\text { final } 59 \text { subjects in each group, } 2 \text { subjects in the neostigmine } \\
\text { group were excluded due to "major protocol violations". }\end{array}$ & $\checkmark$ & & \\
\hline 4 & $\begin{array}{l}\text { Were patients, health workers, and study personnel } \\
\text { 'blind' to treatment? Patients were blinded to the treatment } \\
\text { they received. The anesthesiologist administering the } \\
\text { randomized study drug was not blinded but was prohibited } \\
\text { from revealing the assigned treatment group to the safety } \\
\text { assessor postoperatively. Study personnel in the post- } \\
\text { operative period were blinded to the treatment subjects } \\
\text { received. }\end{array}$ & & & $\checkmark$ \\
\hline
\end{tabular}




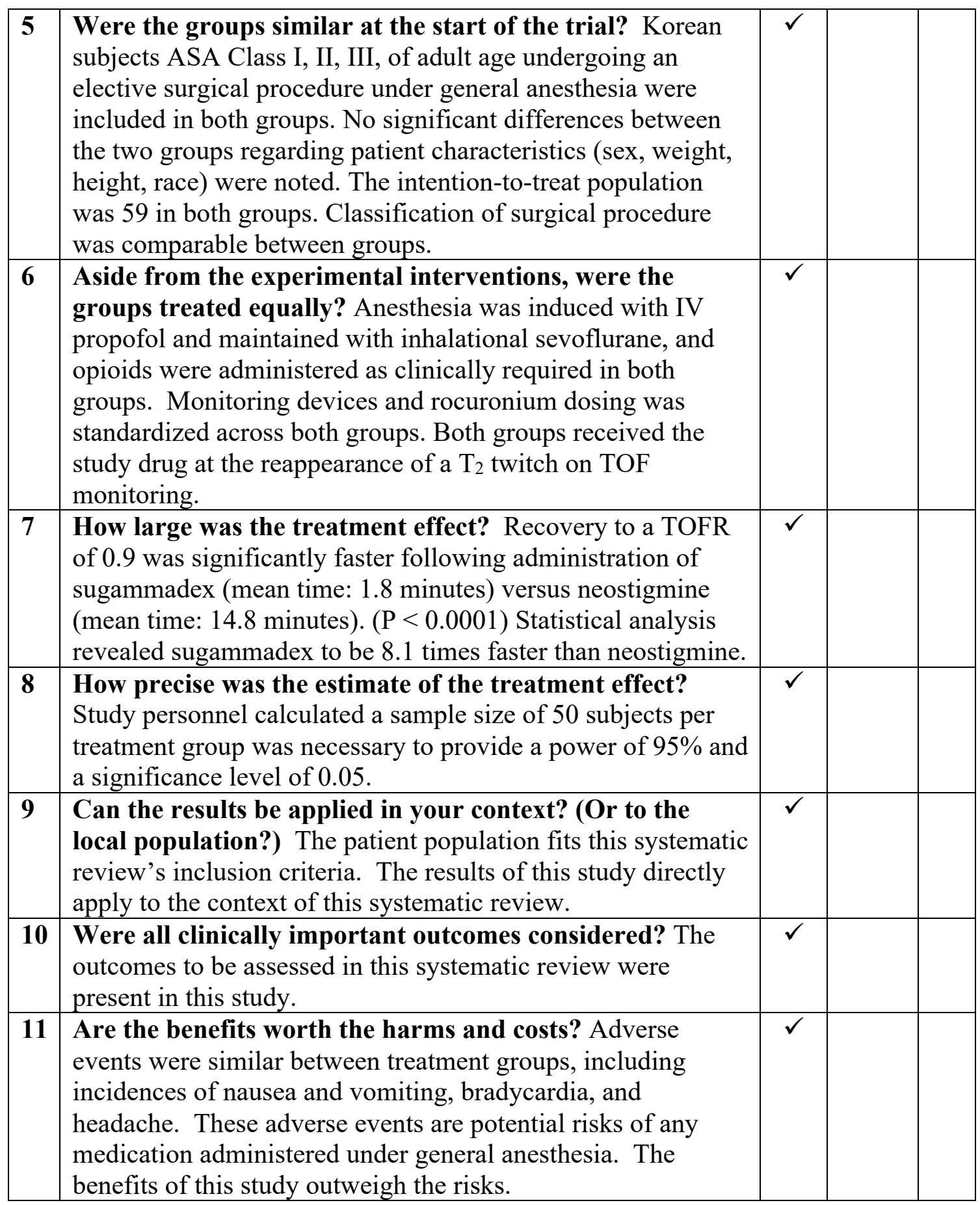


Table E3 - Gaszynski, T., Szewczyk, T., \& Gaszynski, W. (2011). Randomized

comparison of sugammadex and neostigmine for reversal of rocuronium-induced muscle

relaxation in morbidly obese undergoing general anaesthesia. British Journal of

Anaesthesia, 108(2), 236-239. doi: 10.1093/bja/aer330

\begin{tabular}{|c|c|c|c|c|}
\hline & 11 Questions & Yes & $\begin{array}{c}\text { Can't } \\
\text { Tell } \\
\end{array}$ & No \\
\hline 1 & $\begin{array}{l}\text { Did the trial address a clearly focused issue? The study } \\
\text { specifically focused on the efficacy of sugammadex versus } \\
\text { neostigmine for reversal of rocuronium-induced } \\
\text { neuromuscular blockade in morbidly obese patients } \\
\text { undergoing elective bariatric surgery. }\end{array}$ & $\checkmark$ & & \\
\hline 2 & $\begin{array}{l}\text { Was the assignment of patients to treatments } \\
\text { randomized? Subjects were randomized into two groups by } \\
\text { a process of using previously prepared envelopes. }\end{array}$ & $\checkmark$ & & \\
\hline 3 & $\begin{array}{l}\text { Were all the patients who entered the trial properly } \\
\text { accounted for at its conclusion? } 70 \text { trial participants were } \\
\text { randomized into two groups. } 35 \text { subjects were allocated into } \\
\text { each group to receive either neostigmine or sugammadex. } \\
\text { Data from all } 70 \text { participants was analyzed at the conclusion } \\
\text { of this study. }\end{array}$ & $\checkmark$ & & \\
\hline 4 & $\begin{array}{l}\text { Were patients, health workers, and study personnel } \\
\text { 'blind' to treatment? Patients who consented to study } \\
\text { enrollment, were blinded to whether they received } \\
\text { sugammadex or neostigmine for reversal of rocuronium- } \\
\text { induced neuromuscular blockade. The anesthesia provider } \\
\text { administering the anesthetic was not blinded to treatment. } \\
\text { The postoperative study investigator was blinded to the } \\
\text { treatment received. }\end{array}$ & & & $\checkmark$ \\
\hline 5 & $\begin{array}{l}\text { Were the groups similar at the start of the trial? Both } \\
\text { groups were electively proceeding with weight loss surgery } \\
\text { under general anesthesia. Physical characteristics of age, } \\
\text { weight, height, BMI, and total rocuronium administered was } \\
\text { similar between groups. ASA classification was not reported } \\
\text { (Given the surgery is elective, ASA classifications I, II, III, } \\
\text { IV would be included). Both groups had an equal sample size } \\
\text { of } 35 \text { participants. }\end{array}$ & $\checkmark$ & & \\
\hline 6 & $\begin{array}{l}\text { Aside from the experimental interventions, were the } \\
\text { groups treated equally? Anesthesia was induced and } \\
\text { maintained similarly, and standard monitoring was consistent } \\
\text { between groups. At the appearance of a } T_{2} \text { twitch, study } \\
\text { medications were administered according to the }\end{array}$ & $\checkmark$ & & \\
\hline
\end{tabular}




\begin{tabular}{|c|c|c|c|}
\hline & $\begin{array}{l}\text { randomization process and the time to achieve a TOFR of } 0.9 \\
\text { was measured. }\end{array}$ & & \\
\hline 7 & $\begin{array}{l}\text { How large was the treatment effect? Time to TOFR of } 0.9 \\
\text { for patients who received sugammadex was } 2 \text { minutes } 44 \\
\text { seconds (mean time }=2.7 \text { minutes). Time to TOFR of } 0.9 \text { for } \\
\text { patients who received neostigmine was } 9 \text { minutes (mean time } \\
=9.6 \text { minutes). Mean time to achieve a TOFR of } 0.9 \text { was } 3.5 \\
\text { times shorter in the sugammadex group }(\mathrm{P}<0.05 \text { ). Of note, } \\
\text { the TOFR was } 0.9 \text { by the time the patient arrived in the } \\
\text { PACU for every case that received sugammadex. }\end{array}$ & $\checkmark$ & \\
\hline 8 & $\begin{array}{l}\text { How precise was the estimate of the treatment effect? } \\
\text { Statistical analysis was performed using a Microsoft Excel } \\
\text { workbook. The authors did not clearly identify the sample } \\
\text { size needed to provide a power analysis. Additionally, the } \\
\text { authors do not report a power analysis. A significance level } \\
\text { of } 0.05 \text { was calculated. }\end{array}$ & & $\checkmark$ \\
\hline 9 & $\begin{array}{l}\text { Can the results be applied in your context? (Or to the } \\
\text { local population?) Yes, the results of this study can be } \\
\text { applied to the context of this systematic review. The patient } \\
\text { population fits this systematic review's inclusion criteria. }\end{array}$ & $\checkmark$ & \\
\hline 10 & $\begin{array}{l}\text { Were all clinically important outcomes considered? The } \\
\text { outcomes to be assessed in this systematic review were } \\
\text { present in this study. }\end{array}$ & $\checkmark$ & \\
\hline 11 & $\begin{array}{l}\text { Are the benefits worth the harms and costs? Two patients } \\
\text { who received sugammadex reported a strange taste in their } \\
\text { mouths, no other side effects from sugammadex were } \\
\text { reported. Three patients who received neostigmine were } \\
\text { observed to be bradycardic. No further side effects from } \\
\text { neostigmine were reported. The benefits of this study } \\
\text { outweigh the risks. }\end{array}$ & $\checkmark$ & \\
\hline
\end{tabular}


Table E4 - Illman, H.L., Laurila, P., Antila, H., Meretoja, O., Alahuhta, S., \& Olkkola, K.

T. (2011). The duration of residual neuromuscular block after administration of

neostigmine or sugammadex at two visible twitches during train-of-four monitoring.

Anesthesia \& Analgesia, 112(1), 63-68. doi: 10.1213/ANE.0b013e3181fdf889

\begin{tabular}{|c|c|c|c|c|}
\hline & 11 Questions & Yes & $\begin{array}{c}\text { Can't } \\
\text { Tell }\end{array}$ & No \\
\hline 1 & $\begin{array}{l}\text { Did the trial address a clearly focused issue? Yes, the main } \\
\text { objective of this study was to determine the time gap between } \\
\text { the } T_{2} \text { twitch to the return of a TOFR of } 0.9 \text { when either } \\
\text { neostigmine or sugammadex was administered for reversal of } \\
\text { rocuronium-induced neuromuscular blockade. }\end{array}$ & $\checkmark$ & & \\
\hline 2 & $\begin{array}{l}\text { Was the assignment of patients to treatments randomized? } \\
\text { Anesthetized patients were randomized to receive either } \\
\text { sugammadex or neostigmine at the conclusion of their surgical } \\
\text { procedure. Randomization was achieved by using computer- } \\
\text { generated sealed envelopes. The envelope contained written } \\
\text { instructions to prepare either neostigmine or sugammadex. }\end{array}$ & $\checkmark$ & & \\
\hline 3 & $\begin{array}{l}\text { Were all the patients who entered the trial properly } \\
\text { accounted for at its conclusion? All } 50 \text { patients who } \\
\text { enrolled in the study were accounted for at conclusion. } 25 \\
\text { patients were allocated into each group to receive either } \\
\text { neostigmine or sugammadex. Data from } 2 \text { patients who } \\
\text { received neostigmine and } 1 \text { patient who received sugammadex } \\
\text { was excluded for technical failure of equipment and } \\
\text { awakening from anesthesia before a TOFR of } 0.9 \text { was } \\
\text { established. Therefore, data from } 47 \text { patients was resulted. }\end{array}$ & $\checkmark$ & & \\
\hline 4 & $\begin{array}{l}\text { Were patients, health workers, and study personnel 'blind' } \\
\text { to treatment? Patients who consented to study enrollment } \\
\text { were blinded to which treatment they received. The anesthesia } \\
\text { provider was blinded to treatment, as the study drug was } \\
\text { prepared and administered by the study nurse. The study } \\
\text { investigators were blinded to treatment. }\end{array}$ & $\checkmark$ & & \\
\hline 5 & $\begin{array}{l}\text { Were the groups similar at the start of the trial? Both } \\
\text { groups were comprised of men and women aged 18-70 years } \\
\text { undergoing elective surgical procedures with ASA } \\
\text { classifications I, II, III, IV. No significant differences between } \\
\text { the groups based on gender, age, body mass index, or ASA } \\
\text { classification was detected. }\end{array}$ & $\checkmark$ & & \\
\hline 6 & $\begin{array}{l}\text { Aside from the experimental interventions, were the } \\
\text { groups treated equally? All patients received general } \\
\text { anesthesia. Anesthesia induction and maintenance was }\end{array}$ & $\checkmark$ & & \\
\hline
\end{tabular}




\begin{tabular}{|c|c|c|c|}
\hline & $\begin{array}{l}\text { maintained with a volatile agent and opioids. Standard } \\
\text { monitoring devices were utilized. Both groups received the } \\
\text { study drug at the reappearance of a } T_{2} \text { twitch on TOF } \\
\text { monitoring. }\end{array}$ & & \\
\hline 7 & $\begin{array}{l}\text { How large was the treatment effect? Patients who received } \\
\text { sugammadex recovered to a TOFR of } 0.9 \text { significantly faster } \\
\text { than patients who received neostigmine. Return to a TOFR of } \\
0.9 \text { in neostigmine group: } 10.3 \pm 5.5 \text { minutes. Return to a } \\
\text { TOFR of } 0.9 \text { in sugammadex group: } 0.3 \pm 0.3 \text { minutes. } \\
(\mathrm{P}<0.0001)\end{array}$ & $\checkmark$ & \\
\hline 8 & $\begin{array}{l}\text { How precise was the estimate of the treatment effect? The } \\
\text { authors calculated a sample size of } 23 \text { patients in each group } \\
\text { would be required to demonstrate a significance level of } 0.05 \\
\text { and power of } 90 \% \text {. A total of } 50 \text { patients were enrolled. } 23 \\
\text { patients received neostigmine and } 24 \text { patients received } \\
\text { sugammadex. The authors determined there was a statistical } \\
\text { significance in patients who received sugammadex versus } \\
\text { neostigmine }(\mathrm{P}<0.0001)\end{array}$ & $\checkmark$ & \\
\hline 9 & $\begin{array}{l}\text { Can the results be applied in your context? (Or to the local } \\
\text { population?) Yes, the results of this study can be applied to } \\
\text { the context of this systematic review. The patient population } \\
\text { fits this systematic review's inclusion criteria. }\end{array}$ & $\checkmark$ & \\
\hline 10 & $\begin{array}{l}\text { Were all clinically important outcomes considered? A } \\
\text { TOFR of } 0.9 \text { was calculated for all patients enrolled in this } \\
\text { study. The outcomes to be assessed in this systematic review } \\
\text { were present in this study. }\end{array}$ & $\checkmark$ & \\
\hline 11 & $\begin{array}{l}\text { Are the benefits worth the harms and costs? One patient } \\
\text { who received neostigmine reported postoperative nausea. No } \\
\text { other adverse events were reported. The benefits outweigh the } \\
\text { harms and costs. }\end{array}$ & $\checkmark$ & \\
\hline
\end{tabular}


Table E5 - Blobner, M., Eriksson, L.I., Scholz, J., Motsch, J., Rocca, G.D., \& Prins, M.E.

(2010). Reversal of rocuronium-induced neuromuscular blockade with sugammadex

compared with neostigmine during sevoflurane anaesthesia: Results of a randomized

controlled trial. European Journal of Anaesthesiology, 27(10). doi:

10.1097/EJA.0b013e32833d56b7

\begin{tabular}{|c|c|c|c|c|}
\hline & 11 Questions & Yes & $\begin{array}{c}\text { Can't } \\
\text { Tell }\end{array}$ & No \\
\hline 1 & $\begin{array}{l}\text { Did the trial address a clearly focused issue? Yes, this } \\
\text { study evaluated whether reversal of rocuronium-induced } \\
\text { neuromuscular blockade using sugammadex is faster than } \\
\text { reversal using neostigmine. }\end{array}$ & $\checkmark$ & & \\
\hline 2 & $\begin{array}{l}\text { Was the assignment of patients to treatments } \\
\text { randomized? Randomization was achieved by assigning } \\
\text { codes via a central-randomization system. Patients were } \\
\text { given a number in order by which they enrolled in the study, } \\
\text { and a treatment code was assigned using the randomization } \\
\text { system. }\end{array}$ & $\checkmark$ & & \\
\hline 3 & $\begin{array}{l}\text { Were all the patients who entered the trial properly } \\
\text { accounted for at its conclusion? All } 98 \text { patients who } \\
\text { enrolled in the study were accounted for at conclusion. } 49 \\
\text { patients were allocated into each group to receive either } \\
\text { neostigmine or sugammadex. Data from } 1 \text { patient in each } \\
\text { group was excluded as the patient's did not receive the study } \\
\text { drug. }\end{array}$ & $\checkmark$ & & \\
\hline 4 & $\begin{array}{l}\text { Were patients, health workers, and study personnel } \\
\text { 'blind' to treatment? Patients were blinded to treatment. } \\
\text { The anesthetist was not blinded to the drug administered. } \\
\text { Postoperatively, study personnel were blinded to treatment. }\end{array}$ & & & $\checkmark$ \\
\hline 5 & $\begin{array}{l}\text { Were the groups similar at the start of the trial? All } \\
\text { patients were scheduled for an elective surgical procedure, at } \\
\text { least } 18 \text { years of age and ASA class I-III. Treatment groups } \\
\text { were mostly comparable in terms of their baseline } \\
\text { characteristics (age, weight, and height). The relative } \\
\text { distribution of surgical procedures was similar across the } \\
\text { two groups. }\end{array}$ & $\checkmark$ & & \\
\hline 6 & $\begin{array}{l}\text { Aside from the experimental interventions, were the } \\
\text { groups treated equally? All patients received general } \\
\text { anesthesia. Anesthesia induction and maintenance was } \\
\text { comparable between the two groups. Standard monitoring } \\
\text { devices were utilized. Both groups received the study drug } \\
\text { at the reappearance of a } T_{2} \text { twitch on TOF monitoring. }\end{array}$ & $\checkmark$ & & \\
\hline
\end{tabular}




\begin{tabular}{|c|c|c|}
\hline 7 & $\begin{array}{l}\text { How large was the treatment effect? Patients who } \\
\text { received sugammadex recovered to a TOFR of } 0.9 \text { in a } \\
\text { geometric mean time of } 1.5 \text { minutes. Patients who received } \\
\text { neostigmine recovered to a TOFR of } 0.9 \text { in a geometric } \\
\text { mean time of } 18.6 \text { minutes. Within } 5 \text { minutes of receiving } \\
\text { reversal agents, } 98 \% \text { of sugammadex patients, and } 11 \% \text { of } \\
\text { neostigmine patients, recovered to a TOFR of } 0.9 \text {. The } \\
\text { authors calculated a statistically significant difference in } \\
\text { patients who received sugammadex versus neostigmine } \\
(\mathrm{P}<0.0001)\end{array}$ & $\checkmark$ \\
\hline 8 & $\begin{array}{l}\text { How precise was the estimate of the treatment effect? It } \\
\text { was determined by the authors a sample size of } 46 \text { patients } \\
\text { in each group would be necessary to demonstrate a power of } \\
95 \% \text { and significance level of } 0.05 \text {. }\end{array}$ & $\checkmark$ \\
\hline 9 & $\begin{array}{l}\text { Can the results be applied in your context? (Or to the } \\
\text { local population?) The patient population fits this } \\
\text { systematic review's inclusion criteria. The results of this } \\
\text { study directly apply to the context of this systematic review. }\end{array}$ & $\checkmark$ \\
\hline 10 & $\begin{array}{l}\text { Were all clinically important outcomes considered? Time } \\
\text { to recovery of a TOFR of } 0.9 \text { was a clinically important } \\
\text { outcome assessed in this study. Therefore, the outcomes to } \\
\text { be assessed in this systematic review were present in this } \\
\text { study. }\end{array}$ & $\checkmark$ \\
\hline 11 & $\begin{array}{l}\text { Are the benefits worth the harms and costs? At least one } \\
\text { adverse event was reported in } 84 \text { of the study participants. } \\
\text { Adverse events included: dry mouth, nausea, procedural } \\
\text { hypotension, and vomiting. Adverse events are potential } \\
\text { risks of any medication administered under general } \\
\text { anesthesia. The benefits outweigh the harms and costs. }\end{array}$ & $\checkmark$ \\
\hline
\end{tabular}




\section{Appendix F}

Cross Study Analysis

\begin{tabular}{|c|c|c|c|}
\hline Author & $\begin{array}{c}\text { Time to TOFR of } \\
0.9 \text { with } \\
\text { Sugammadex }\end{array}$ & $\begin{array}{c}\text { Time to TOFR of } \\
0.9 \text { with } \\
\text { Neostigmine }\end{array}$ & $\begin{array}{c}\text { Type of Surgical } \\
\text { Procedure }\end{array}$ \\
\hline Wu et al., 2014 & $\begin{array}{l}1.6 \text { minutes in } \\
\text { Chinese subjects } \\
1.4 \text { minutes in } \\
\text { Caucasian subjects }\end{array}$ & $\begin{array}{c}9.1 \text { minutes in } \\
\text { Chinese subjects } \\
6.7 \text { minutes in } \\
\text { Caucasian subjects }\end{array}$ & Not Specified \\
\hline Woo et al., 2013 & 1.8 minutes & 14.8 minutes & $\begin{array}{l}\text { Operations of the ear, } \\
\text { nose, \& larynx }(48 \%) \\
\text { Operations of female } \\
\text { genital organs }(18 \%) \\
\text { Operations of digestive } \\
\text { system \& spleen }(17 \%)\end{array}$ \\
\hline $\begin{array}{c}\text { Gaszynski et al., } \\
2011\end{array}$ & $\begin{array}{c}2 \text { minutes } 44 \\
\text { seconds }\end{array}$ & 9 minutes & Elective bariatric surgery \\
\hline Illman et al., 2011 & $1.7 \pm 0.7$ minutes & $13.3 \pm 5.7$ minutes & Not Specified \\
\hline Blobner et al., 2010 & 1.5 minutes & 18.6 minutes & $\begin{array}{l}\text { Operations of ear, nose, \& } \\
\text { larynx (19\%) } \\
\text { Operations of teeth, jaws, } \\
\text { mouth, \& pharynx }(16 \%) \\
\text { Operations of digestive } \\
\text { system \& spleen (16\%) } \\
\text { Operations of urinary } \\
\text { system, male genital } \\
\text { organs, \& retroperitoneal } \\
\text { space (13\%) } \\
\text { Operations of } \\
\text { musculoskeletal system }\end{array}$ \\
\hline
\end{tabular}




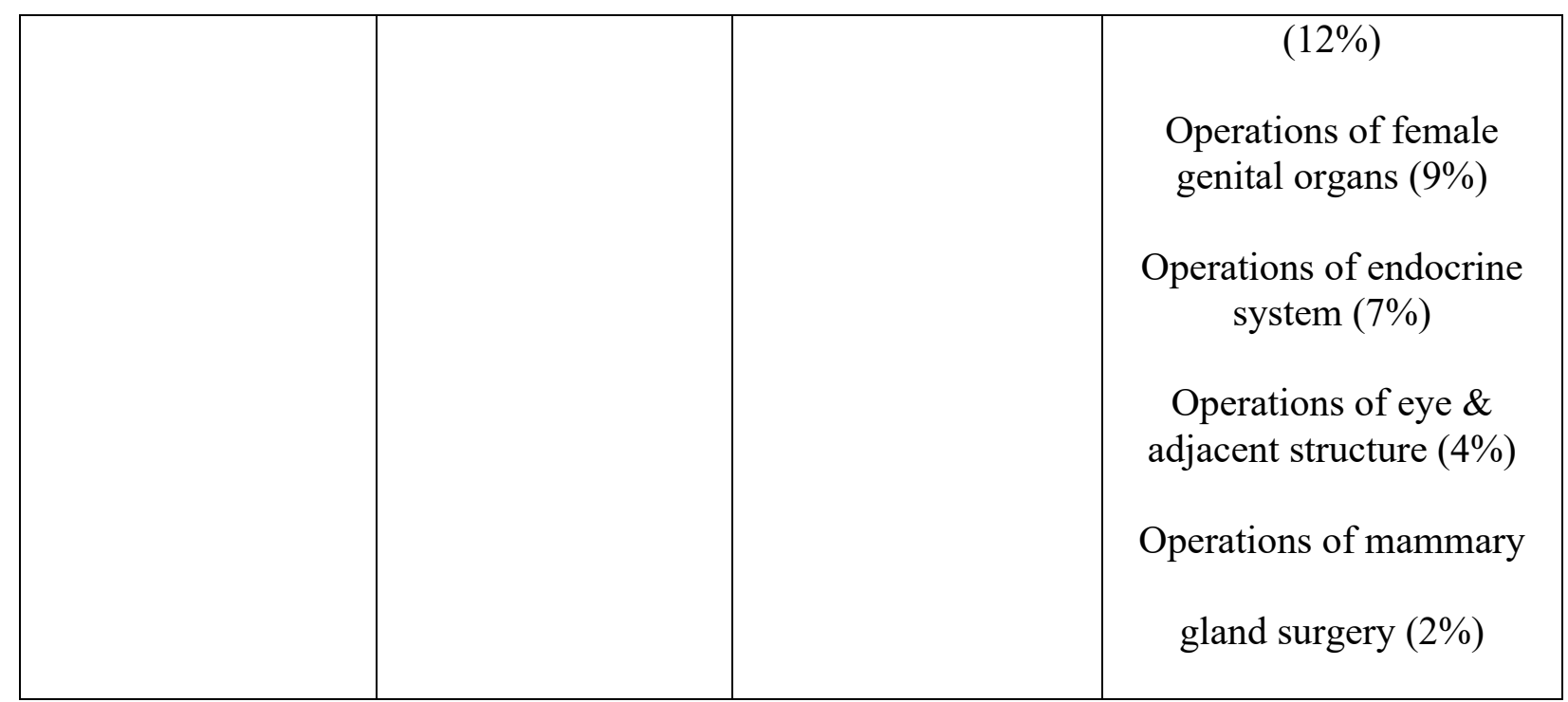

